Document downloaded from:

http://hdl.handle.net/10251/102164

This paper must be cited as:

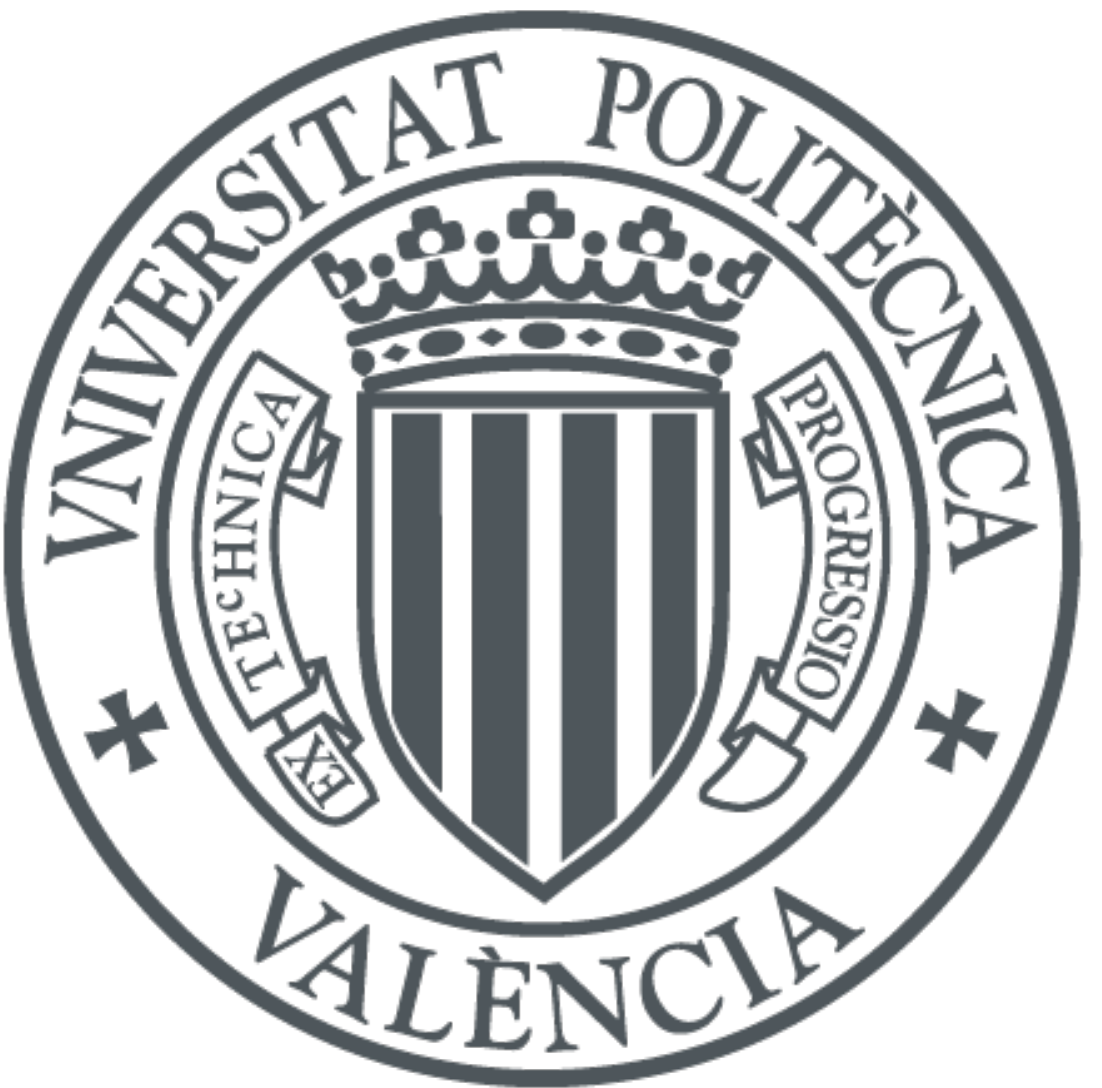

The final publication is available at

https://doi.org/10.1007/s11365-017-0478-z

Copyright Springer-Verlag

Additional Information 


\section{ROWING AGAINST THE WIND: HOW DO TIMES OF AUSTERITY SHAPE ACADEMIC ENTREPRENEURSHIP IN UNFRIENDLY ENVIRONMENTS?}

This is the author's version of a work that was submitted to / accepted for publication.

Citation for final published version: Seguí-Mas, E., Oltra, V., Tormo-Carbó, G., \& SarriónViñes, F. (2017). Rowing against the wind: how do times of austerity shape academic entrepreneurship in unfriendly environments?. International Entrepreneurship and Management Journal, 1-42. https://doi.org/10.1007/s11365-017-0478-z

Elies Seguí-Mas $^{1 *}$ Víctor Oltra $^{2}$, Guillermina Tormo-Carbó $^{3}$, and Faustino Sarrión-Viñes ${ }^{4}$

${ }^{1}(*)$ Corresponding author: Associate Professor in Accounting and Finance. CEGEA, Centre of Business Management Research. Universitat Politècnica de València, Camí de Vera, s/n, 46022 Valencia, Spain. Tel: (+34) 963877007 ext. 84713. Fax. (+34) 963877913 Email: esegui@cegea.upv.es

${ }^{2}$ Associate Professor in Management. Department of Management. University of Valencia. Av. dels Tarongers, s/n. 46022 Valencia, Spain. Tel: +34 963828317 Email: Victor.Oltra@uv.es

${ }^{3}$ Associate Professor in Management. CEGEA, Centre of Business Management Research. Universitat Politècnica de València, Camí de Vera, s/n, 46022 Valencia, Spain. Tel: +34 963877007 ext. 77686 . Email: gtormo@omp.upv.es

${ }^{4} \mathrm{PhD}$ Student. Faculty of Business Management Administration. Universitat Politècnica de València, Camí de Vera, s/n, 46022 Valencia, Spain. Tel: +34 963877007 ext. 84713. Email: fausarvi@ade.upv.es

\section{Acknowledgments}

The authors would like to thank the Universitat Politècnica de València (grant PAID-06-120916), and the Spanish Ministry of Economy and Competitiveness (grant ECO2011-29863), for their financial support for this research. 


\title{
ROWING AGAINST THE WIND: HOW DO TIMES OF AUSTERITY SHAPE ACADEMIC ENTREPRENEURSHIP IN UNFRIENDLY ENVIRONMENTS?
}

\begin{abstract}
Academic spin-offs (ASOs) help universities transfer knowledge or technology through business projects developed by academic staff. This investigation aims at analyzing the critical factors for spin-off creation at universities operating in crisis-raven, entrepreneurship-unfriendly environments. Such factors revolve around four types of resources: environmental, institutional, organizational, and personal. Focusing on a Southern European context, as an example of an unfriendly environment affected by economic crisis, an entrepreneurial university (the Technical University of Valencia in Spain, UPV) is our research setting. Through a case study approach, we examine the potential of UPV as a springboard for ASOs. Our results show an adverse local environment, a rather favorable influence of institutional and organizational drivers, and a mixed role of personal factors. Our findings illustrate that UPV consistently supports spin-off creation due to a greater (rather positive) reflexivity from its institutional, organizational and personal resources than the (negative) imprinting of the unfriendly environment. This helps counter-balance the structural unfriendliness for academic entrepreneurship, and trigger a crisis-led risktaking attitude by academic staff. Hence, UPV should continue with its current strategy of supporting academic entrepreneurship, and might transfer best practices to other universities also affected by adverse environmental conditions. Generally speaking, we would advise universities facing adverse circumstances to develop rules and mechanisms for academic entrepreneurship, carefully revise and improve malfunctions, and become involved throughout the whole process of spin-off development. All in all, our study advances understanding of how the different drivers for ASO creation can be revamped by universities located in unfriendly environments, having in mind the key role that universities play in fostering social and economic development through academic entrepreneurship in such environments.
\end{abstract}

Keywords: Academic entrepreneurship, academic spin-off creation factors, times of austerity; unfriendly environments. 


\section{INTRODUCTION}

As universities are becoming increasingly entrepreneurial (Mosey et al. 2012a; Smilor et al. 1990), attention paid to academic entrepreneurship is rising (Guerrero and Urbano 2012; Morales-Gualdrón et al. 2009). An entrepreneurial university actively seeks to develop its activities in innovative ways, thus fostering ongoing change in its culture and overall organizational character (Clark 1998). Universities have different histories, traditions and organizational structures, shaping their external relations (O'Shea et al. 2005), and fostering different ways to become entrepreneurial (Martinelli et al. 2008). There are some universities that have achieved significant financial success with licensing income (for instance the University of California, Stanford University and Columbia University) or academic spin-offs (ASOs) (for instance Oxford University) (Geuna and Nesta 2006; Mowery et al. 2001a,b). But in the literature there are only good examples to match with friendly environments for entrepreneurship.

Several studies have focused on spin-off creation as a key mechanism of knowledge transfer activities developed by entrepreneurial universities (Bruneel et al. 2013; Powers and McDougall 2005). They are usually considered mechanisms of university knowledge or technology transfer through a business project carried out by university staff (Clarysse and Moray 2004). Spin-offs have an important impact on economic diversification, the fostering of new entrepreneurs, as well as on growth and job creation (Cohen et al. 2002).

Entrepreneurial activities are quite different in their nature, intensity and dynamics depending on the regions considered (Hülsbeck and Pickavé 2014), and in this sense environmental (un)friendliness towards (academic) entrepreneurship varies greatly across countries and regions. The social-cultural, political-legal, technological and economic-business contexts (Lindelöf and Löfsten 2006; O’Shea et al. 2007) can help assess the environmental structural potential of support (or obstruction) for academic entrepreneurship. Southern European regions (Cyprus, Gibraltar, Greece, Italy, Malta, Portugal, San Marino and Spain, according to Eurovoc, 2017) can be considered as relatively unfriendly environments for academic entrepreneurship (Algieri et al. 2013; Hofstede 1980, 2001; Piperopoulos and Piperopoulos 2010; Vargas Vasserot 2012). Moreover, the recent economic and financial crises have hit Southern Europe especially hard, with relevant implications for entrepreneurship (Papaoikonomou et al. 2012), also having in mind that environmental dynamism requires especially marked entrepreneurial and proactive market orientations (Lindelöf and Löfsten 2006). The already negative environmental structure for academic entrepreneurship in Southern Europe is reinforced with the especially negative economic conditions that are currently experienced in this region. This extremely negative environment for (academic) entrepreneurship, especially in terms of the creation of ASOs, has been under- 
studied. We believe that deepening into this scenario is worthwhile, as we address a stimulating research gap. In this sense, our investigation aims at offering a novel resource map - and how different resources interact with each other for ASO creation, taking into account a critical factor as a key basis for the analysis: the environment - and particularly its unfriendliness for academic entrepreneurship. To explore these dynamics, we chose the case of an entrepreneurial university in Spain, particularly the Technical University of Valencia.

An important aspect to have in mind to analyze the key resources for ASO creation is the tension between, on the one hand, the relevance of the social and historical influence of the context on the entrepreneurs' opportunities (imprinting) and, on the other, the entrepreneur's abilities to overcome the environmental constraints (reflexivity) (Suddaby et al. 2015). That is, on the one hand, social and historical contexts have a deep influence in delimiting the range of opportunities for innovation available to entrepreneurs. This perspective on the environment's role in entrepreneurship has been identified as imprinting, defined as "the profound influence of social and historical context in constraining the perceptual apparatus of entrepreneurs and delimiting the range of opportunities for innovation available to them" (Suddaby et al. 2015: 1-2). Accordingly, the external environment is perceived as rather concrete and unchanging, and the barrier between the entrepreneur and the environment is substantially sharp and distinct (Suddaby et al. 2015).

On the other hand, reflexivity "refers to an assumptive high degree of self-awareness of the entrepreneurial actor to the constraints constructed by the social, political and economic context within which the entrepreneur is embedded" (Suddaby et al. 2015: 6-7). Reflexivity plays a counter-balancing role in improving the ability of entrepreneurs to overcome environmental constraints to entrepreneurship. Insights wrought by reflexivity permit the entrepreneur "not only to identify these constraints, but also to envision alternate institutional arrangement" (Suddaby et al. 2015: 7). Compared to an imprinting view, when an entrepreneurial opportunity rises as the result of the entrepreneur's reflexivity, a much more malleable description of the environment within which entrepreneurs are embedded is also adopted: the external environment is perceived to be less concrete and inflexible, and more amenable to being reconstructed (Suddaby et al. 2015).

Consistent with the above ideas, the so-called "knowledge spillover theory of entrepreneurship" (Acs et al. 2013) implies that a key trigger for fostering entrepreneurship in a given region or country is the connection between the knowledge created in such region's or country's context and the human capital available that takes advantage of such knowledge. This is, "a context that is rich in knowledge generates entrepreneurial opportunities from those ideas" 
(Acs et al. 2013: 757). On the one hand, contextual knowledge richness (or scarcity) can be closely related to institutional and organizational-level reflexivity, for instance when knowledge incubators promoted by universities develop new ideas and produce $R \& D$ results that can have a potential impact on the society as a whole (Acs et al. 2013; Fritsch and Aamoucke 2013; Leyden and Link 2013). On the other hand, the availability of astute human capital willing to use "spilled" knowledge for entrepreneurial endeavors can be considered as an important component of individual-level reflexivity. As a result, dynamics of mutual reinforcement or both organization and individual-level reflexivity dynamics might - to some extent - counter-balance negative environmental conditions for (academic) entrepreneurship. Interestingly, the potential role of universities in these dynamics has been highlighted form various perspectives, such as (i) universities’ catalyzing effect on knowledge spillovers (Leyden and Link 2013; RodríguezGulías et al. 2017), (ii) their influence as key actors in regional public research and higher education (Fritsch and Aamoucke 2013), and (iii) universities' specific specializations as a significant determinant of firm creation across industries at a local level (Bonaccorsi et al. 2013).

A situation of environmental unfriendliness for (academic) entrepreneurship, coupled with economic crisis and austerity in entrepreneurship-support policies, can become particularly hostile for R\&D expenditure (Moutinho et al. 2016) and ASOs. Needs of funding and overall support for entrepreneurship, especially complicated in times of crisis, are even more difficult to meet in the case of ASOs, given the high-risk related idiosyncrasies of this type of new business ventures (Papaoikonomou et al. 2012).

The aim of this investigation is to analyze the critical factors for spin-off creation in an entrepreneurial university operating in unfriendly environments which are also experiencing times of austerity. The Technical University of Valencia in Spain (Universitat Politècnica de València, UPV), a relatively young and entrepreneurial institution, is our research setting as a singular example of a university where its reflexivity can win the imprinting of the environment. That is why we consider explaining how to beat unfriendly environments as a worthwhile story to tell.

UPV is an entrepreneurial university because it is heavily focused on knowledge transfer. It was the leading Spanish university in terms of returns obtained from licensing contracts in 2014 (Red OTRI 2016). Growth in income from this concept (between $5 \%$ and $10 \%$ per annum) is highly relevant, especially considering the intense economic crisis in its social-economic context (Papaoikonomou et al. 2012). Besides, UPV is among the five Spanish universities with higher license revenue, number of patents and income from collaborative R\&D projects (Red OTRI 2016). 
Different types of resources have been pinpointed as drivers of ASO creation, such as environmental, institutional, organizational, and personal resources (O'Shea et al. 2008). Through case study analysis, our investigation examines the potential of UPV as a springboard for ASOs. In this sense, with our research, we also expect to deepen into the understanding of the dynamics of the tension between imprinting and reflexivity in entrepreneurship-unfriendly environments under a situation of austerity. Specifically, we expect to be able to observe, explain, understand, and draw conclusions from analyzing the "downstream" (environmental-institutionalorganizational-personal factors) imprinting influences, and also the "upstream" (personal-organizational-institutionalenvironmental factors) reflexivity influences.

The interest of the UPV case lies upon its highly relevant features (young, technical, knowledge transfer intensive, unfriendly environment, times of austerity, etc.), which establish a study context especially prone to facilitating the identification of good practices and challenges ahead (Martinelli et al. 2008). Furthermore, by analyzing how different types of external and internal resources jointly affect academic entrepreneurship, we are also addressing a call for studies that approach academic spin-off formation under "an integrated consideration of motivation and framework conditions" (Kroll 2009: 97).

This article is structured as follows. The next section introduces the conceptual foundations of the different types of resources that influence ASO creation. In a third section, the research setting is explained and methodological issues are tackled. In the fourth section, according to the prior theoretical framework, the results of our study are described and analyzed. In the final (discussion and conclusion) section of this article, the most important findings, contributions and implications of the study are highlighted.

\section{ACADEMIC SPIN-OFFS AND THE CRITICAL RESOURCES FOR THEIR CREATION}

The different resources that may support ASO creation can be classified according to diverse types. Going from broader (macro) to narrower (micro) levels of analysis, O'Shea et al. (2008) identify four types of resources: environmental (i.e. external to the university), institutional (e.g., university mission, vision, culture, history and tradition), organizational (e.g. university assistance and funding), and individual (e.g., founders' personal traits and characteristics) resources. We will base our subsequent (theoretical and empirical) analyses on this classification. In this way, we also aim at contributing to addressing calls for a better integration of rather fragmented and heterogeneous 
literature on aspects related to academic entrepreneurship into stronger and more consistent theoretical frameworks (Schmitz et al. 2017).

\subsection{Environmental resources}

External relations can improve formalization of knowledge exchange and transfer processes leading to spinoff creation. Thus, some authors underlined the relevance of networks for spin-off success (Hoang and Antoncic 2003) and how the university spin-offs perform better as their network capability enhances (Walter et al. 2006). Specifically in the case of the southern European countries such as Spain or Portugal, networking is especially relevant for business performance (Moutinho, et al. 2016). Therefore, the access to knowledge from other institutions, information on customer needs, or building good working relationships with partners or well-known business people, allow better conditions to launch and develop new products or services successfully (Walter et al. 2006).

The external environment includes people, experiences, technology, and related formative interactions between individual entrepreneurs and their external environment. In some cases, these elements create ideal conditions within which entrepreneurs can discover and exploit opportunities (Mathias et al. 2015). Thus, the environmental factors most analyzed in the extant literature as main determinants of spin-off creation are the social-cultural, politicallegal, technological, and business-economic contexts (O'Shea et al. 2007).

Regarding the social-cultural context, risk aversion varies greatly across cultures, societies, regions and countries. In this respect, Southern European societies, generally characterized by high levels of "uncertainty avoidance" (cf., Hofstede 1980, 2001), tend to overstate the risks over the potential benefits of setting up new businesses, and also tend to punish business failure, compared to more risk-prone attitudes in the low uncertainty avoidance cultures typical of Northern European and Anglo-Saxon societies (Hofstede 1980, 2001). Accordingly, in low uncertainty avoidance cultures professional success has been typically defined by getting promotions through job

changes and launching one's own businesses (Hofstede 1980, 2001). Hence, high risk-oriented societies in terms of business making consider business failure as a normal step and a learning opportunity, and provide a structurally friendly environment for entrepreneurship.

As for the political-legal context, public administrations play a relevant role to support spin-off creation (Bruneel et al. 2013). Consequently, policy makers should develop specific plans aimed at stimulating the creation and consolidation of these companies, consistent with the relevance of (broader) entrepreneurship-enhancing policies 
(Autio et al. 2014). As an example, Italian ASOs have traditionally faced relevant barriers such as the lack of specific support measures, including university-level incentives, local context support mechanisms, or the availability of internal venture capital (Grandi and Grimaldi 2005).

Concerning the technological context, the more technologically advanced the environment, the greater the potential for entrepreneurial innovation (Autio et al. 2014). In this sense, countries with higher penetration of hightech industries offer a more friendly context for academic entrepreneurship (O'Shea et al. 2007). Southern Europe is not characterized by providing a context where hi-tech activities thrive, hence hindering (academic) entrepreneurship (Piperopoulos and Piperopoulos 2010; Vargas Vasserot 2012).

Finally, regarding the business-economic context, academic entrepreneurship is expected to be fostered by a dynamic and growing economy led by high value-added activities. Thus, university knowledge transfer activities crucially nurture and sustain the development of a knowledge-based economy grounded on high-value added products and services (Guerrero and Urbano 2012; Yusof and Jain 2010). Moreover, university and industry can act jointly in diverse ways depending on the risk and commitment levels that they wish to take. Informal networks also tend to facilitate more formal relationships, links and collaborative research. Hence, external participation facilitates change towards more applied research (Martinelli et al. 2008).

All in all, and particularly from an imprinting approach (cf., Suddaby et al., 2015), the overall assessment of the social-cultural, political-legal, technological, and business-economic contexts, helps define the structural (un)friendliness of the environment in terms of its (positive or negative) influence towards academic entrepreneurship. Having the above considerations in mind, the Southern European environment can be regarded as structurally unfriendly towards academic entrepreneurship. Furthermore, financial and economic crises, especially persistent in Southern Europe, have led governments to cut public investment, with university funding being heavily affected. The structurally unfriendly context for (academic) entrepreneurship existing in Southern Europe is thus worsened by the current situation of austerity. The economic crisis arrived hand in hand with an unprecedented period of financial austerity. Although this situation may harm the survival of current university spin-offs and the creation of new ones (Papaoikonomou et al. 2012), startups in general and (academic) spin-offs in particular may also offer interesting options for obtaining alternative (or complementary) sources of income and new employment opportunities (Cohen et al. 2002). These latter dynamics of creating opportunities in a context of crisis and austerity can be linked to a reflexivity-based construction of the external environment (cf., Suddaby et al. 2015). According to this view, 
entrepreneurs do not just let themselves to be driven by the (hostile) external forces, but behave proactively to build and develop new opportunities, especially under university-triggered knowledge spillover contexts (Acs et al. 2013; Leyden and Link 2013; Rodríguez-Gulías et al. 2017).

\subsection{Institutional resources}

The evolution of the role of institutional resources is consistent with the increasingly popular transition from traditional universities (based on teaching and research) towards entrepreneurial universities (also focused on entrepreneurship) (Yusof and Jain 2010). Hence, universities' mission, vision, culture, history and tradition, have been regarded key triggers for ASO creation (Lockett and Wright 2005; Martinelli et al. 2008). In fact, a university with a good history in terms of exploiting its research outcomes will be able to effectively promote a knowledge spillover based context for (academic) entrepreneurship (Acs et al., 2013; Leyden and Link, 2013) and, more specifically, will succeed at motivating researchers to patent their outputs or to launch new spin-offs (Moutinho, et al. 2016).

Emphasis on the relevance of different institutional characteristics (O’Shea et al. 2008) is supported by many empirical studies (e.g., Lockett and Wright 2005; Powers and McDougall 2005). For instance, the greater the university tradition in entrepreneurial tasks, the better developed the staff's skills and capabilities necessary to manage entrepreneurial processes, so staff will be more efficient at knowledge transfer activities (Lockett and Wright 2005). Furthermore, scholars' perceptions that a university department has a high entrepreneurial orientation may positively affect such academics' engagement into entrepreneurial activities (Kalar and Antonic 2015). In this context, universities can be expected to play an active role in enhancing their faculty's entrepreneurial behaviors (Guerrero et al. 2014). Besides, in the Southern European context, universities' institutional strategies should focus on fostering academic entrepreneurship, in close synergy with dynamics of entrepreneurs' human capital exploitation of knowledge spillovers (Acs et al., 2013; Leyden and Link, 2013), and in this sense strengthening researchers' broader social capital, dynamics that eventually have positive effects on spin-off activity (Moutinho et al. 2016).

\subsection{Organizational resources}

Universities' organizational resources are also crucial for spin-off creation (Link and Scott 2005; O’Shea et al. 2005; Smilor et al. 1990). These resources can be grouped into a number of categories, such as the availability of a network of technology transfer offices (TTOs) and other support units, funding assistance, as well as the overall 
quality of the academic staff involved. Policy makers' support to spin-off creation has often implied modifying organizational contexts (Wright et al. 2007). Generally speaking, availability of universities, incubator or technology parks, access to venture capital funds, and knowledge of potential investors or partners, are decisive factors for creating spin-offs. More specifically, the presence of venture capitalists, the capacity to generate internal funds or the capacity to work in high-tech sectors (Rodríguez-Gulías et al. 2017), the availability, size and experience of TTOs (Fritsch and Aamoucke, 2013; Link and Scott 2005; O’Shea et al. 2005; Powers and McDougall 2005), as well as the development of R\&D incubators that promote knowledge spillovers (Acs et al., 2013; Leyden and Link, 2013), can crucially support spin-off creation and growth. The availability of internal funding has been a key determinant in the spin-off growth due to the fact that their main assets are intangible, and they could not be used as a guarantee for banks (RodríguezGulías et al. 2017). In fact, spin-offs are often physically located in science parks, with incubators and entrepreneurship centers also playing a key sustaining role (Link and Scott 2005), especially in spin-off early stages (Clarysse and Moray 2004). Moreover, TTO staff numbers and their business skills play a key role in spin-off creation (Lockett and Wright 2005).

However, some studies, such as Gómez Gras et al. (2008), pointed out mixed results. On one hand, they confirmed the key role of universities financial support mechanisms on their spin-off activity and performance. They also showed the positive effect of training, advice or other "soft" support measures on new spin-off performance. On the other hand, they did not show any influence of university technology transfer policies on their spin-off activity.

Private R\&D spending, the existence of venture capital in the region (O'Shea et al. 2005; Powers and McDougall 2005), and support to academics' social networking (Moutinho et al. 2016), can be also considered important organizational drivers for spin-off creation. Moreover, participation of universities in the capital, royalties, research and researchers' quality (Lockett and Wright 2005), and high research-related income (O'Shea et al. 2005), also stand out as organizational resources for spin-off creation. All in all, departments more involved with industry tend to be more entrepreneurial, and relevant academic entrepreneurs can be found across a variety of fields, mostly related to science, engineering, humanities, and social science disciplines (Martinelli et al. 2008).

\subsubsection{Personal (individual and group) resources}

The study of the characteristics, competences and motivations of academic entrepreneurs is essential to understand the phenomenon of business creation in academia (Kroll 2009; Morales-Gualdrón et al. 2009; Mosey et 
al. 2012b; Mosey and Wright 2007; Smilor et al. 1990). Individual attitudes and motivations constitute our first set of personal resources. Individual attitudes such as entrepreneurship education, teaching methodologies, role models, and reward systems, influence entrepreneurial intentions (Guerrero and Urbano 2012). Entrepreneurial attitudes and intentions from academic staff have been identified as the most critical factor shaping entrepreneurial universities in Spain (Guerrero and Urbano 2012). Besides, the main individual motivations for academic entrepreneurship have been found to relate to the market (market pull), followed by technology development (technology push), personal reasons and, finally, resources and infrastructure availability (Autio and Kauranen 1994). The main personal motivations that have been studied stem from individual expectations and goals. Among them, the need of independence, the sense of achievement, and the desire of wealth, stand out (Doutriaux and Peterman 1982). Other motivations also noted have been to contribute to science and its applications (i.e. knowledge related) (Samsom and Gurdon 1990), and identification of a market opportunity (Chiesa and Piccaluga 2000).

From an ASO approach, Grandi and Grimaldi (2005) support the importance of articulating roles within the founding team, and also the relevance of setting up relations with external agents, and thus combining different types of knowledge coming from outside companies' boundaries. On the one hand, it is critical to access this knowledge through external relations, and academics should know the main market requirements. On the other hand, factors such as prior experiences or familiarity affecting business ideas articulation depends on the stage of the new venture. Within the European context (e.g. Spain and Italy), De Cleyn et al. (2015) showed the relevant role of the founding team heterogeneity and legal expertise in the early development of ASOs, mainly because the required expertise is unlikely to be found in a single person and the increasing relevance of contracts and intellectual property rights.

As for the professional career expectations, the characteristics that define academic entrepreneurs revolve around being at the end of their professional careers, having a high status in the parent organization, a broad work experience, and being usually among the best in their field of expertise in the moment of creating the spin-off (Franzoni and Lissoni 2006).

Finally, important entrepreneurs' characteristics include their potential as qualified human capital to effectively optimizing knowledge spillovers (Acs et al., 2013), their ability to develop social capital and networking (Mosey et al. 2012b; Mosey and Wright 2007), excellence of academic staff, family environment and friends, prior experience in business startups, and risk aversion. Shapero and Sokol (1982) pointed out that those individuals coming from families with parents who were business people are more likely to start their own businesses. Ashcroft et al. 
(2004) evidenced that business people have a greater disposal towards risk taking. In fact, there seems to be consensus around the fact that business owners are individuals who assume moderate risks and in this respect they do not differ substantially from managers (Gartner 1985). Prior experience in business startups has also been related to a positive and significant effect on the probability of creating a company (Shane and Khurana 2003), in line with the fact that prior business ownership experience leads to more effective social networks which are beneficial to academic entrepreneurs (Mosey and Wright 2007). In this sense, the aforementioned study by De Cleyn et al. (2015), pointed how the links between different types of prior entrepreneurial experience and ASO survival was most important at the top management team level. Moreover, Gómez Gras et al. (2008) showed how the existence of leading researchers as academic entrepreneurs was associated with the spin-off activity and performance of these new ventures.

\section{RESEARCH SETTING AND METHODS}

\subsection{Research setting: The Technical University of Valencia}

The Technical University of Valencia (Universitat Politècnica de València, UPV) is located in the Autonomous Community of Valencia (an autonomous region in the East of Spain). Nowadays, Valencia is the fourth Spanish region in terms of population (10.62\%) and GDP (9.4\%) (INE 2016). It is worth noting the dominance of SMEs (99.91\% of all companies in Valencia), similar to the Spanish level (99.8\%)(MIET 2012). Thus, the Valencian economy, rather specialized in labor-intensive activities due to their traditionally low labor costs (but also small productivity) (Soler i Marco 2009), is a little more industrialized than the overall Spanish one (14.40\% of industrial workers vs. $11.50 \%$ of Spanish average) (INE 2016). Valencia has placed itself in a leading position among other export-oriented Spanish regions, with the export activity being currently the driving force of the Valencian economy (León-Darder 2016).

The seed of what today is UPV appears in 1968 as a part of a higher education reform, whereby Spanish universities were substantially transformed, and new types of technology-oriented universities were created. This reform gave higher autonomy to universities, popularized access to the "social masses", and increased research orientation (although with insufficient resources) (Redero San-Román 2002; Rodríguez-San Pedro 2014). Currently, the UPV community is made up of 32,800 students, 2,550 teaching and research staff, and 1,560 services personnel (UPV 2015). UPV was in 2014 one of the Spanish leading universities (top five) in three fields: (1) collaborative R\&D 
projects, (2) number of patents and (3) incomes from licenses (Red OTRI 2016). Besides, UPV is among the top 500 universities worldwide in 2017 according to the Academic Ranking of World Universities (the "Shanghai Ranking') (ARWU 2017), and among the 150 best worldwide under 50 years old, according to the ranking Times Higher Education 150 Under 50 (The Times Higher Education 2017).

During the past decade, the UPV has turned its efforts towards becoming an internationally renowned center of excellence, promoting the exchange and mobility of students, teachers, and researchers. Thus, in 2014, UPV was the fourth among the Spanish universities in the number of incoming Erasmus students (also the sixth among all participating universities worldwide), and the fifth in outgoing students (European Commission 2017). UPV participates in two campuses of international excellence (VLC/Campus and CampusHabitat5U), funded by the Spanish Government under the International Campus of Excellence Program (VLC/Campus 2017; CampusHabitat5U 2017). Indeed, regarded as an example of Spanish entrepreneurial university in the Spanish context (Guerrero and Urbano 2012), UPV has been consistently supporting the creation of spin-offs, including the promotion of the "UPV spin-off" brand, the use of university facilities, etc. (UPV 2017a). Accordingly, UPV approved the "UPV 2015-2020 Strategic Plan", which includes the Entrepreneurship Strategic Venture (UPV 2017e), aimed at capitalizing knowledge developed at the university by boosting the creation of research-based TBFs.

\subsection{Research approach}

A case study research strategy has been followed. According to Yin (1994), case studies are empirical investigations which examine contemporary phenomena within their real-life contexts, especially when the boundaries between the phenomena and their surroundings are not clearly evident. Multiple sources of evidence (interviews, surveys and documentation) were used. In order to study the phenomenon of ASO creation through a case study research strategy, all current spin-offs at UPV comprise the research setting. Accordingly, this study explores the influence of the determinant resources for UPV spin-off creation.

The approach of this research focuses on assessing the extent to which the different resources for spin-off creation have contributed rather positively or negatively to the launching of the ASOs. The most important level in our inquiry is, however, the university, as its structure, history, dynamics and policies are the key sources that inform our assessment of the institutional and organizational resources. 


\subsection{Data collection}

In the data collection process, three procedures were applied to strengthen research validity and increase transparency of our investigation: case-study protocol, questionnaire to spin-offs, and triangulation. First, the casestudy protocol provided structure to the data collection process, and operated as a checklist to make sure that all topics were included. It comprised questions on the academics' motivations and other personal resources, the impact of environmental factors, the relevance of organizational and institutional resources, and the impact of austerity. For primary data collection, we conducted five semi-structured interviews (all were transcribed verbatim) to capture different viewpoints, establish comparability and improve the reliability of our data. Interviews were made to selected people with managerial responsibilities from different university units: (1) the Head and (2) Vice-director of the UPV TTO, (3) the Head of UPV Science Park, (4) the President of the local Business Angels association, and (5) a UPV Professor of Business Law (specialized in Intellectual property). All the interviews took place in Valencia and had an average of 45:26 minutes (3:47:09 in total). Table 1 shows the key data of the interviews.

--- Insert Table 1 here ---

Later, based on the results of the interviews, we designed a questionnaire aimed at assessing the perceptions of individuals in charge of each of all current UPV spin-offs on different issues related to ASO creation and development (identified as a critical by the experts). We gathered academic entrepreneurs' perceptions of UPV involvement in spin-off creation, specifically related to environmental, institutional, organizational and personal resources. According to the final categories found in the interviews analysis, we made different questions based on the ASO literature in the Spanish context (Morales-Gualdrón et al 2009; Ortín et al. 2007).

The study population for the questionnaire included all 19 spin-offs officially registered in the UPV at the end of 2016. People in charge of the spin-offs were targeted online for questionnaire completion. 10 questionnaires, which took around twenty minutes to complete, were returned properly completed, resulting in a response rate of $52.6 \%$, and. Participation was voluntary. The questionnaire consisted of four sections (see appendix).

In the first section of the questionnaire, respondents answered questions related to Firm's Characteristics (FC) such as industry, sales or number of employees. This section aimed at identifying patterns or singularities related to specific FC. Responses to questions in this first section usually were numbers, but also included string answers. The 
second section of the questionnaire addressed the company's Funding (F): sources, difficulties and the effect of the austerity. Different scales (Yes/No, and four and five-point Likert-type scales) were used in this part of the questionnaire.

The third section of the questionnaire addressed Institutional and Organizational Resources (I\&OR): problems and support. Respondents were asked to rate the importance of, on the one hand, nine potential types of problems regarding I\&OR and, on the other hand, UPV support on 12 specific types of issues related to I\&OR (see details in appendix). A four-point Likert-type scale was used in this part of the questionnaire, whereby a rating of 1 meant "No impact" and a rating of 4 meant "Extreme impact".

Finally, the fourth section of the questionnaire measured Personal Resources (PR), revolving around three distinct areas: personal motivations for entrepreneurship, external influences on individual entrepreneurship decisions, and entrepreneurship-related risk perceptions (see details in appendix). A four-point Likert-type scale was also used in this part of the questionnaire, whereby a rating of 1 meant "No important" and a rating of 4 meant "Very important".

In addition, we arranged data triangulation (Creswell and Clark, 2011) by using data collected from the spinoff questionnaire, the semi-structured interviews and also secondary data gathered from relevant UPV's corporate information and from other official reports. According to Eisenhardt (1989), triangulation gives stronger substantiation of constructs and propositions, so data we can improve their reliability and increase the richness of the case-study evidences through the use of these secondary data.

Table 2 shows an overview of each of the 19 current UPV spin-offs, which have been the focus of our investigation.

\section{--- Insert Table 2 here ---}

\subsection{Data analysis}

Our analysis combines established techniques of qualitative analysis for theory development, supported by some basic, descriptive quantitative analyses. Qualitative analysis implies travelling back and forth between the data and the emerging structure of theoretical argument in an iterative manner (Gibbert and Ruigrok, 2010).

As for our qualitative analysis, regarding the semi-structured interviews, we used the three steps of analysis from Miles and Huberman (2008): data reduction, data display and drawing and verifying conclusions. First, we reduced the data from transcriptions by means of deleting repetition or not related contents, and after that we 
recognized the identification units (the elements of the discourse with meaning and interest according our research goals). We used "words" as identification units. Second, we coded the summarized content of each interview. As a consequence, we created a list of provisional categories. After that, we searched similarities and differences among the provisional categories, creating the set of 1st-order concepts through the combination of similar meanings. Thus, after several iterations, we condensed each group of theoretically relevant concepts in a set of 2 nd-order themes. Moreover, following these steps, we examined several corporate documents to compare the expert perceptions with the institutional point of view. This comparison let us to confirm (or not) the interpretations derived from interview data.

Finally, we quantitatively analyzed the data from the questionnaires. We used descriptive statistics according to the type of the variables included (scalar, Likert, etc.).

\section{RESULTS}

Despite the deep economic and financial crises that started in 2009 in Spain, ASO creation at UPV has kept steadily growing. As shown in Figure 1, the first UPV spin-off was founded in 2005. Since then, and while the latest Spanish economic boom lasted (2005-2008), six UPV spin-offs were created. In the year 2009 the economic crisis begun and one UPV spin-off was created. During the following crisis years (2010-2015), and rather contrary to expectations, UPV spin-off creation grew considerably, with fourteen spin-offs founded in the 2010-2015 five-year period (compared to seven spin-offs created in the also five-year 2005-2008 pre-crisis period). All in all, 11 out of the 19 UPV spin-offs that currently exist (survival rate is $90.48 \%$; two out of 21 failed in 2015) have been founded in times of austerity.

--- Insert Figure 1 here ---

We have structured our findings across the O'Shea et al.'s (2008) four categories of resources (i.e., environmental, institutional, organizational, and personal). In particular, we expose the idiosyncrasy of these resources in the context of unfriendly environments for entrepreneurship under austerity. Regarding the interviews, we use following abbreviations for experts: TTO-H (Head of Technology Transfer Office), TTO-V (Vice-Director of Technology Transfer Office), SP (Head of Science Park), BA (President of local Business Angels) and PBL (UPV Professor of Business Law). 
After the data reduction, we coded the content of the interviews. Thus, as the analysis units, we obtained the most cited words. In tables 3 and 4 we offer the main data displays: first, the most cited words; and second, the categorization with the keywords related (our set of 2 nd order theme).

--- Insert Table 3 here ---

--- Insert Table 4 here ---

In tables 3 and 4 many of the keywords are related to weaknesses of the spin-off at the first stage. Thus, through an iterative process, we identified three main categories of interest: context of funding (related to the environment), organization (related to institutional and organizational characteristics), and people (related to personal attributes).

We develop the last step of Miles and Huberman's (2008) analysis (drawing and verifying conclusions) within the next sections dedicated to O'Shea et al.'s (2008) four categories of resources. 


\subsection{Environmental resources}

The external factors reviewed above in the theoretical framework are comprised by the social-cultural, political-legal, technological, and business-economic contexts. As explained below, the environmental resources in our study setting are, generally speaking, not appropriate for (academic) entrepreneurship.

The social-cultural context in Spain - a high uncertainty-avoidance society (Hofstede 1980, 2001) - does not encourage risk-taking in business. Hence, the Spanish society can be regarded as highly risk-averse and fearful of failure towards entrepreneurship (Alemany 2011). Our study results are consistent with these ideas. In particular, interviewees acknowledged relevant social-cultural barriers for business venturing in general and academic entrepreneurship in particular.

However, the recent economic and financial crises, especially hard in Southern Europe and particularly in Spain, which have caused painful cuts in public investment (notably including R\&D and support for entrepreneurship), may have eventually encouraged the creation of ASOs. In this sense, facing lower salaries and uncertain career prospects, some academics may be more motivated than ever to set up their own businesses, trying to find new opportunities for financial security and professional development.

The Spanish political-legal context has not been traditionally favorable for academic entrepreneurship (Vargas Vasserot 2012). However, some changes have been made in regulations during the last decade, which seem to be on the right track to provide a friendlier context for academic entrepreneurship. Overall, a formal political-legal framework for Spanish ASOs has only been recently introduced, lacking legal development and focused on recognizing the relevance of knowledge transfer - but not on encouraging it. Accordingly, other notable weaknesses are the high complexity, dispersion and, especially, unfinished implementation of this political-legal framework (Vargas Vasserot 2012).

The "University Act" (LOU 2001) is considered an important milestone in setting the foundations for Technology-Based Firms (TBFs), and generally speaking as a tool for dissemination and exploitation of university research results, as was all as to regulate the participation mechanisms of its research staff (Vargas Vasserot 2012). However, it was not until a few years ago, when this law was modified (LOMLOU 2007), that it achieved significant progress on regulating university-promoted TBFs (e.g., by dropping some faculty incompatibilities). Even so, there is still an overall situation of legal uncertainty because, after many years since the enactment of LOMLOU (2007), the government has not yet developed specific regulations of key aspects. Hence, universities have been compelled to 
autonomously implement their particular developments. More recently, the "Sustainable Economy Act" (LES 2011) and the "Science, Technology and Innovation Act" (LCTI 2011), have not led to significant legal advances compared to LOU (2001). The latest relevant law is the "Act of Support to Entrepreneurs and their Internationalization" (LAEI 2013). This is a broad regulation on promoting an entrepreneurial culture and tax incentives, without explicit mention of academic entrepreneurship or any pending developments. Regarding our study results, spin-off promotion potential of business startup support policies is assessed as average-to-low, compared to other local environmental factors. According to President of CV-BAN interviewed:

"A new legislation to launch new businesses with more guarantees for academics is needed" ... "Current ASO legislation in Spain is damaging the ability to create new high added value firms because spin-offs need people on full time and exclusivity“... "Another issue is that universities do not value entrepreneurship" ... “Universities prioritize publications, not creating firms; so, academics produce publications" (BA)

As for the technological context, according to our interviews and survey data there is a positive assessment of basic technical infrastructures, which provide a reasonably good framework for entrepreneurship. Science parks and business incubators, as well as the high professionalism of technical staff of TTOs, stand out as boosters of spinoff creation and development. The assessment of the access conditions to infrastructures and professional and commercial services is also positive. The technological environment and the possibilities for technology transfer also get an average-to-low assessment. A relatively good assessment, though, is received by the potential of science and technology to trigger the creation of competitive companies. However, startups have an added problem, that is, the financial cost of the latest technologies. According to the Vice-Director of UPV TTO interviewed, "local companies do not know how to add knowledge to their businesses. They only buy equipment.” (TTO-V)

Last, but not least, the local business-economic situation does not seem appropriate for creating ASOs. The high indebtedness of public administrations (related to the times of austerity), the difficult access to funding (which is also crucial for spin-off survival and growth), the high unemployment rate, and a business context dominated by small and middle-sized firms without investment prospects, are factors that pose serious obstacles to academic entrepreneurship. According to our study results, agents involved in UPV spin-off creation deem the local economic context not appropriate for creating TBFs. This is closely related to an unfavorable position with respect to venture capital and, specifically, to a dominant local culture which is risk-averse to investing in non-traditional sectors. Several statements made by the Vice-Director of UPV TTO, by the Professor of Business Law, by the Head of UPV Science 
Par, and also by the President of CV-BAN, during the interviews conducted, support this rather gloomy assessment of the business-economic context:

"Private funding is complicated at the moment" ... "Spin-offs need a kind of high level private funding, different than usual" ... "People who usually invest in technology firms are needed. This is an important problem for ASOs" ... "Spin-Offs need a different kind of businessman than the traditional one in Spain. It's hard to find local businessmen who want to collaborate with spin-off companies" ... "Finding businessmen who want to share risk with researchers is needed" ... "To generate this private investing network is difficult in a endogenous way"... "When the spin-off grows, money is what it needs. The transferred knowledge never finishes its development at the university" ... "In knowledge-based businesses, venture capital is key because knowledge has a window of opportunity" (TTO-V).

"The commercialization is the biggest challenge after the introduction. The company needs funding but also sales and clients (contacts, networking)" ... "It's really hard to obtain venture capital for these businesses" ... "Society (institutions, companies, investors...) and the university are too separated. There is no recognition of the worth of academic research" ... "The environment is not prone to develop. The economic structure of our companies (SMEs, low value added, poor innovation culture) is not favorable for academic entrepreneurship" ... "There is a problem of business culture. Researchers are not businessmen" (PBL).

"Local investors are not prone to invest in technological businesses. They do not know this kind of business, their risks, etc. and they prefer traditional activities" (SP).

"Local companies do not really support innovation and collaboration"... "The crisis (and the following austerity) brought the decline of traditional investments and big volatility. In this context, investing in startups became a real alternative (with risk). However, if the investor adds contacts and knowledge with his/her funds, the mortality rate falls down" (BA)..

From the questionnaire, we observed that another relevant aspect of ASOs is their financial structure (see Table 5). The most regular funding source of UPV spin-offs comes from the founders themselves, accounting for $69.3 \%$ of liabilities. This figure is similar to the $67 \%$ overall figure for Spanish startups (Güemes 2011). Following in importance are friends and family, with almost $13 \%$ of liabilities; and venture capital, universities and suppliers, which fund around $6 \%$ each. Finally, there is no contribution at all from financial institutions to UPV spin-off funding. This 
last result is not surprising, given the structurally high aversion to risk-taking in terms of business venturing in Spain (Hofstede 1980, 2001; Alemany 2011). This situation is even worsened by the recent financial crisis in Spain and, in particular, austerity policies and heavy credit restrictions, which have especially hit Spanish SMEs (Martínez Carrascal and Mulino Ríos 2014) - precisely the most common type of firm among ASOs.

--- Insert Table 5 here ---

Another survey question inquired about the perception on the procedures involved in public subsidies (ease and speed) (table 6). In the first stage, the procedures for public subsidies do not seem to involve too much complication for most UPV spin-offs in terms of obtaining funding. After this first stage, in general, UPV is the main support of these ASOs (in terms of training, information services, incubator support, or business plan development). The second institution more valued for respondents was CDTI (Center for Technological Industrial Development, Spanish Ministry of Industry) due to their information services and to develop the business plan. The Chamber of Commerce or any other institutions of a regional scope (i.e. specific to Valencia region) were not valued.

--- Insert Table 6 here ---

Finally, in times of austerity, we thought it was relevant to ask about the evolution of the access to funding (table 7). Even for this kind of companies, the perception of the evolution is negative: an appalling $80 \%$ of respondents think that the access to funding has worsened during the last years, and the remaining $20 \%$ consider that it has not changed. It is noteworthy to highlight that nobody assessed access to funding to have improved.

--- Insert Table 7 here ---

Accordingly, a local business context dominated by low value added activities, with little innovation in products and services, and with a scarce number of companies to which to transfer university-created knowledge, are factors that complete the rather gloomy picture in terms of opportunities for academic entrepreneurship. 
All in all, the environmental resources in our study setting are not appropriate for (academic) entrepreneurship. This outcome is especially consistent with an imprinting view of environmental influences on entrepreneurship (cf., Suddaby et al. 2015), whereby opportunities are basically discovered only if favorable conditions exist. Conversely, if conditions are hostile, as it is our case, the imprinting influence of the environment prevents entrepreneurial opportunities from revealing themselves, and thus exploitation chances are severely hindered.

\subsection{Institutional resources}

UPV has its own regulations on research-derived business startups, covering all aspects involved in the creation of spin-offs: the business creation procedures, the "UPV spin-off” brand, the approval of UPV's participation in the capital, relationships between the spin-off and UPV, contractual clauses, use of university facilities, etc. (UPV 2017a). Careful analysis of these regulations leads to conclude that they are not restrictive; on the contrary, they seem to be helpful for spin-off creation, establishing all the necessary steps for their founding and subsequent continuity. Besides, UPV approved the "UPV 2015-2020 Strategic Plan", which includes as strategic challenges the transfer of results at national and international level. Among its projects, the Entrepreneurship Strategic Venture (UPV 2017e) stands out. This latter plan is meant to contribute to capitalizing knowledge developed at the university by fostering the creation of TBFs stemming from research activities. In fact, UPV has been regarded as an example of Spanish entrepreneurial university within the "consolidation stage" (Guerrero and Urbano 2012). Thus, the so-called technology transfer mission of the university, the entrepreneurial education, and the support measures, are institutionalized.

Despite the entrepreneurship-hostile Spanish environment (i.e. an entrepreneurship unfriendly environment coupled with a situation of austerity), data shown above may place UPV as one of the most entrepreneurial and industry-oriented Spanish universities (Guerrero and Urbano 2012). The fact of being a relatively young university in Spain is probably a beneficial factor in terms of its change-oriented values and culture, and high dynamism and flexibility. UPV's focus on applied research, revolving around practical technologies which help solve real technical challenges, make UPV highly appealing to businesses, which are generally keen on collaborating with this university. All in all, entrepreneurial universities - as it is UPV's case - have academic staff who have proved their capabilities of transferring relevant knowledge (Lockett and Wright 2005). UPV is one of the Spanish leading universities in patent exploitation (Red OTRI 2016), and it is amongst the top 500 universities in the world in 2017 according to the 
Academic Ranking of World Universities (the "Shanghai Ranking") (ARWU 2017). It is also considered the best technical university in Spain (ARWU 2017), and it is ranked among the 150 best universities in the world under 50 years old, according to the ranking Times Higher Education 150 Under 50 (The Times Higher Education 2017).

Regarding mission, vision, history, culture and tradition, UPV shows a keen willingness to transfer knowledge by supporting the creation of TBFs. The UPV's mission statement points out that "UPV educates people in order to enhance their skills; researches and generates knowledge, with the assurance of quality, rigor and ethics, in the fields of science, technology, art and business, with the aim of furthering the integral development of society and contributing to its technical, economic and cultural progress". In turn, UPV's vision statement claims that "UPV is an innovative and entrepreneurial University, with effective mechanisms for the dissemination of scientific and technological results, and which excels in the training of researchers and in the creation of technology-based companies." (UPV 2017e). This predisposition is also reflected on UPV's history. Consistent with the broader trend of developing academic multidisciplinary institutes aimed at research-based knowledge transfer (Mosey et al. 2012a), in 1992 UPV pioneered the launching of an entrepreneurship-supporting program (IDEAS Institute) among Spanish universities (UPV 2007). It can be therefore stated that mission, vision, culture, history and tradition are not an obstacle for spin-off creation at UPV (UPV 2017e).

Overall, the institutional resources developed by UPV seem to help counter-balance, to some extent, the unfriendliness of the external environment. In this sense, UPV's strategy, structure, and general research and technology transfer policies appear to - despite overall external hostility - foster UPV scholars' willingness to engage into entrepreneurial activities. This situation may be linked to factors that propel "downstream" positive imprinting towards organizational and personal resources, in turn helping increase reflexivity (cf., Suddaby et al. 2015) by potential (academic) entrepreneurs, whereby the environment is re-interpreted and opportunities are pro-actively created and not just discovered. Furthermore, such opportunities are, to some extent propelled by knowledge spillovers at an institutional level, in turn optimized by individual-level human capital held by academic entrepreneurs (Acs et al., 2013; Leyden and Link, 2013).

\subsection{Organizational resources}


The availability of TTOs, incubators, technology and science parks, and other units and activities that support spin-off development, are essential for the creation of new TBFs (Link and Scott 2005; O'Shea et al. 2005). UPV has been transferring research results for more than 20 years, through a series of mechanisms, as explained below.

First, the TTO is UPV's executive unit in the area of technology transfer (UPV 2017c). It is responsible for fostering and managing knowledge creation activities and scientific and technical collaboration. It enhances relationships between UPV researchers and the business environment, and also propels researchers' participation in a number of programs that support R\&D activities (UPV 2017c). Specifically, in 2014 UPV had 9 employees (including part-time figures) in its TTO and received $€ 21.02$ million in competitive calls for research and $€ 15.39$ million in competitive research projects (Red OTRI 2016).

Second, the IDEAS Institute was created in 1992 as one of the first programs in Spain to support university entrepreneurship (UPV 2007). It aims at fostering and developing an entrepreneurial culture at UPV, raising awareness among the university community for creating and supporting new companies, and sustaining the creation and development of innovative TBFs. The IDEAS Institute establishes communication channels with entrepreneurs, providing advice and improving possibilities of locating business opportunities in its environment. The four-year success rate of the companies that use the IDEAS Institute's services has increased up to $80 \%$ (Willoughby et al. 2013). More recently, every School at UPV has launched an Entrepreneur Space: students can receive professors' advice and make their first steps into entrepreneurship (UPV 2014). As the president of CV-BAN stated: "IDEAS developed a sensational task" (BA)

Third, through its activities (conferences, workshops, investor's days, etc.) and its 140,000 square meters, the UPV Science Park tries to configure an ecosystem useful for entrepreneurship and technology transfer (UPV 2017b). Around its open collaboration network, a flexible structure brings together public and private agents. These agents voluntarily share their knowledge and resources (research institutes, ASOs, research labs, business and investors' associations, and non-profit foundations). One of these private agents is CV-BAN, a Business Angels Network that aims at providing capital from private investors, knowledge and management expertise, as well as a broad contact network, to UPV startups that have been newly created or are in a growth stage. Similarly, the venture capital fund Tech Transfer UPV has been launched in 2016 by Clave Mayor (fund management office) and the UPV. Following the Oxford University's model, this is the first experience in a Spanish public university to support specific technology transfer projects. More than 25 investors participate in the fund (notably including the Valencian Regional 
Government, the regional cooperative bank Caixa Popular and the Valencia-based airline Air Nostrum) with $€ 3.5$ million (Tech Transfer UPV 2016). This novelty within the Spanish academic context tries to involve universities, public administration and private investors to develop academic start-ups (in line with the solutions suggested by Rodríguez-Gulías et al. 2017). In its first round, were collected 26 projects to invest up to $€ 500.000$ in 4 years. In July 2016 Tech Transfer UPV launched its second round (UPV 2017d). The aim of the fund is to invest $€ 6$ million in 7 years in 21 UPV start-ups with high potential impact.

In addition, UPV Corporation, despite being a rather failed initiative, also deserves mention. This entity was created in 2011 within the framework of UPV's 2007-2014 Strategic Plan, and aimed at facilitating the creation of new TBFs (UPV 2017e). UPV Corporation was expected to be a holder of ownership, and a platform for attracting investors, providing institutional trust and reputation, and selecting projects and supporting professional management (UPV 2011).

Moreover, UPV promotes academic entrepreneurship through diverse courses, conferences, other activities developed by the Permanent Training Centre, and specialized units at different Schools (UPV 2014). Thus, key resources and capabilities can be substantially improved thanks to UPV involvement, consistent with an above-average level of entrepreneurial activities at UPV within the Spanish university context (Guerrero and Urbano 2012).

According to our survey data, the least helpful organizational resources for UPV spin-offs have been the relationships with the science park and the incubator, as well as the (poor) management of the resources contributed by UPV in the startup process (see Table 8).

--- Insert Table 8 here ---

Our survey results also indicate a link between the degree of involvement of UPV with spin-offs at the moment of their creation with prior advice given to develop a business plan, the institutional support, and the transfer or rent of facilities (UPV offers spin-offs the possibility of placing themselves in its science park). On average, UPV spin-off founders consider that they have received considerable support in the process of business creation. However, they also think that support has been rather poor as regards the reduction of academic duties, contribution to seed capital, payment of patent-related costs, and help with business contacts (see Table 9). 
As for UPV spin-off funding access possibilities, there was a clear response: $71 \%$ of respondents believe that access to funding has worsened in the last two years, a situation that hinders growth of these firms. This result is in accordance with the Spanish current context of austerity, and particularly the banking over-indebtedness and the subsequent credit rationing (Martínez Carrascal and Mulino Ríos 2014).

Let us now focus on the main spin-off funding sources at the time of founding. These sources consisted of public subsidies, founders' own capital, and contributions from suppliers, customers, and the entrepreneurs' social circles (see Figure 2). It is surprising that, according to survey respondents, business angels and venture capital companies did not contribute at all to spin-off founding capital. Despite our survey results, business angels and venture capital companies do exist in the UPV environment and they provide funding at latter stages of spin-off development.

\section{--- Insert Figure 2 here ---}

In sum, UPV's organizational resources provide a mixed picture in terms of their potential to boost (or hinder) academic entrepreneurship. On the one hand, some aspects are closely related to an imprinting view (cf., Suddaby et al., 2015) of the (unfriendly) external environment, especially those issues related to funding opportunities. On the other hand, some UPV initiatives seem to provide a rather optimistic and hopeful framework for construing environmental constraints as possible to overcome. The IDEAS Institute, the TTO, and some elements of the Science Park, can be placed among these latter (entrepreneurship-friendly) UPV initiatives. In turn, these initiatives, through "downstream" positive imprinting towards personal resources, may well help foster reflexivity (cf., Suddaby et al., 2015) among UPV scholars, thus increasing the likelihood of starting new entrepreneurial ventures - by creating opportunities - compared to the gloomy picture offered by an imprinting view of the (hostile) external environment. In this sense, similar to the situation regarding the institutional level at UPV, the reflexivity-boosted emergence of entrepreneurial opportunities seems to be, to some extent, propelled by knowledge spillovers at an organizational level, in turn optimized by individual-level human capital held by academic entrepreneurs (Acs et al., 2013; Leyden and Link, 2013). 


\subsection{Personal (individual and group) resources}

Regarding our study results, the interviewees identified personal resources as the most important ones in both stages of introduction and growth of spin-offs. Importantly, management problems stand out as the origin of specific obstacles in this respect: academics are not necessarily good managers. Accordingly, knowledge transfer via spin-offs is more complex than via licensing or patents, since managerial competences are needed with the first method. Several statements made by the Vice-Director of UPV TTO, by the Professor of Business Law, by the Head of UPV Science

Park, and also by the President of CV-BAN, during the interviews conducted, support this rather gloomy assessment of the business-economic context:

"Researchers have mixed motivations. On the one hand, they want to take advantage of things they made. On another hand, they want to create economic units to offer opportunities to personnel" ... "To earn money is not decisive" ... "Team is the most important point (will, development...) and it must count on its product development but also managerial function" (TTO-V).

"A professor is not a manager. A researcher can be a very skilled person in one topic, but maybe does not know how to manage a business" ... "The two main reasons in my opinion are ego and money (get rich quickly)" (PBL).

"There are two profiles regarding researchers' motivations: (1) to earn money based on an business opportunity, and (2) the challenge to launch a business idea with high impact based on the researcher's knowhow (many times lead by a young researcher without tenure)" ... "The star-scientific is not an entrepreneur, is still the most cited, with many articles in prestigious journals" ... "The most important factor in the launch is the leader. If he/she has energy and will, and he/she has a good business idea, he/she can avoid the effects of the unfriendly environment. The rest of factors help, but they are not key" ... "After de launch, the team is what's most important. Funding is also critical to develop businesses." (SP)

"One of the main problems in ASOs is that there are no people to be able to make everything (research, management...)" ... “An investor usually is looking for a committed, competent and consolidated leader/team (generally in scalable businesses) (BA).

--- Insert Table 10 here --- 
As shown in Table 10, and in line with prior literature (Samsom and Gurdon 1990), knowledge related personal motivations are a key driver for academic entrepreneurship. The desire to apply knowledge to practical ends is the most frequently cited (in the interviews) and most important reason (in the survey) for deciding to create a UPV spin-off. After this motivation, the aspiration of independence and the achievement of business opportunities or personal challenges comprise the second main group of incentives for creating UPV spin-offs.

Regarding the wealth motivation, here we find mixed results if we compare the data survey with the interviews. Increasing personal wealth is one of lowest motivations according to the survey, although it was more significant in the interviews. Besides, in relation with the extant literature, only $12 \%$ of entrepreneurs of Weatherston's (1995) study considered the wish of wealth as an important motive for the new business creation. According to our data, UPV spin-off agents and also UPV spin-off themselves consider a wealth motivation, on average, reasonably important. In this sense, the average score (on a 4-point scale) of the wealth motivation in our survey was 2.714 , which is above the middle point (2.00) of the scale. However, getting our results closer to the literature evidence, motivation for wealth is ranked in the 8th position out of 10 possible motivations for academic entrepreneurship. Furthermore, independence aspirations constitute another very important factor for spin-off creation, both in our study and in the literature (Gartner 1988).

Besides, the stage in the researcher's academic career expectations in the moment of spin-off creation also needs to be considered. According to Franzoni and Lissoni (2006), most entrepreneurs create their spin-offs at the end of their careers. This is consistent with the assumption that young scholars prioritize investing time in building a strong publication record so as to achieve a tenured position - in a context that often keeps academics exclusively focused within their peer review research networks (Mosey et al. 2006). Once researchers enjoy a more comfortable status they can devote more time to entrepreneurial activities - something that happens in more advanced career stages. This behavior is observed in the case of UPV spin-offs. According to our survey results, at the moment of joining a spinoff, $72 \%$ of entrepreneurs were already tenured scholars, $14 \%$ were doctoral students or had recently completed their $\mathrm{PhD}$, and the remaining $14 \%$ were temporary post-doctoral researchers.

--- Insert Table 11 here --- 
Regarding entrepreneurs' influences, evidence on the influence of family role models is scarce. For instance, Doutriaux and Peterman (1982), in their study of Canadian ASO founders, found out that only $20 \%$ of academic entrepreneurs had business-owning parents. As Table 11 shows, UPV spin-off founders regard the fact of having relatives who are entrepreneurs as not relevant in their decision to create the new company. The examples of successful companies are the main motivation among the survey respondents, whereas the attitude from society towards entrepreneurship is the lowest in importance.

--- Insert Table 12 here ---

Finally, risk perceptions in UPV spin-offs also fits the literature predictions (see Table 12). Academic entrepreneurs are especially prone to take risks, considering the (personal and business) financial risk as the greatest risk perceived by them, whereas their career risk is regarded as less important.

All in all, personal resources at UPV seem to be the most prone to facilitate a reflexivity-based (cf., Suddaby et al., 2015) construction of (academic) entrepreneurship. Scholars themselves show a number of personal characteristics and motivations which, in turn fostered by institutional and some organizational resources (through positive imprinting), actively counter-balance the imprinting-driven (cf., Suddaby et al., 2015) unfriendliness of the external environment. Definitely, and very clearly in the case of personal resources, the reflexivity-boosted emergence of entrepreneurial opportunities seems to be, to a great extent, facilitated by high-quality individual-level human capital held by academic entrepreneurs, who can effectively optimize knowledge spillovers that originate an the institutional and organizational levels (Acs et al., 2013; Leyden and Link, 2013).

\section{DISCUSSION}

Our research findings show that, despite the overall hostile environment, the target university of our study (Technical University of Valencia, UPV) is making remarkable efforts to support spin-off creation. Certainly, such efforts may counter-balance, to some extent, the structural unfriendliness for academic entrepreneurship, thus triggering a risk-taking attitude that austerity times seem to foster among academic staff. In other words, the structural unfriendliness of the environment, which is linked to an imprinting construction of contextual influences, is confronted by an attitude of reflexivity by academic entrepreneurs (cf., Suddaby et al., 2015). Through reflexivity, scholars create 
opportunities in a hostile context, whereby austerity acts as a trigger for their pro-active behavior, leading to spin-off foundation. Thus, our study offers a recent and novel example of how certain aspects related to reflexivity, developed internally at the institutional, organizational and personal levels, can successfully counter-balance the hostile context fostered by environmental imprinting. Table 14 includes a summary of the assessment made regarding the influence, at UPV, from each of the four types of resources for spin-off creation. Table 13 also includes a brief comparison of UPV results vs. previous studies, and also some hints on recommendations for UPV and other universities in unfriendly environments.

--- Insert Table 13 here ---

First, the environmental resources are the most negatively assessed in our study in terms of their hostility for academic entrepreneurship. These resources do not pass the minimum standards required to reasonably support academic entrepreneurship. Clearly, we consider this situation as worse than most other environmental influences detected in prior investigations. A gloomy picture is offered by all four types of environmental resources assessed, namely the social-cultural context, the political-legal context, the technological context, and the business-economic situation. May we remind the idea that the environmental unfriendliness found in our study setting is particularly acute, as it is the result of the combined action of, on the one hand, a well-established structural inadequacy of, cultural trends, historical patterns and public policies and, on the other hand, a current situation of austerity in terms of cuts in (private and public) funding and investment that severely damage (academic) entrepreneurship opportunities. This negative environmental outlook implies, in our research setting, a negative influence from the imprinting side of contextual influences towards academic entrepreneurship. This situation of environmental unfriendliness is rather different from prior research, as most prior studies were conducted in friendlier environments. Our recommendation for UPV would be to try to counter-balance environmental unfriendliness with strong policies aimed at boosting institutional, organizational and personal resources. As seen above - and as will be reminded below too - UPV is currently devoting keen efforts in this direction. We would suggest UPV to stay on this track, and we would recommend other universities in unfriendly environments (in Spain or elsewhere) to follow UPV example.

Second, regarding institutional resources, a supporting institution and a range of organizational resources offered by it may well help catalyze entrepreneurial plans, which seems to be the case at UPV. Among the resources 
offered by the UPV that support academic entrepreneurship, some of them deserve to be especially reminded. For instance: UPV's entrepreneurship supporting pioneering program launched by the IDEAS Institute a decade ago (UPV 2007); its Entrepreneurship Strategic Venture (UPV2015) and the creation of “UPV spin-off” brand (UPV 2017a); its relevant position in international university rankings (ARWU 2017, The Times Higher Education 2017); and also its longstanding mission, vision, history, culture, and tradition, which have been consistently fostering knowledge transfer, patent exploitation, and TBF development (Red OTRI 2016, UPV 2017e). This supporting institutional context may help explain why, during the economic crisis, spin-off creation has rocketed at UPV, from just six spinoffs in 2008 to 19 in 2015 - the passing of laws such as LOMLOU (2007) and LES (2011) might have also contributed. Academic staff perceive decreased career opportunities and worsened salary conditions. Hence, they can find in spinoff creation an interesting complement to a strictly academic - and currently uncertain - career (Lam and De Campos 2015). Compared to prior research, the situation at UPV seems quite similar to previous studies conducted at entrepreneurial universities. In the case of UPV, as it is a university with an above-average entrepreneurial character within the Spanish context, the institutional resources contribute to counter-balancing the negative environmental outlook. Our recommendation for UPV would be to deepen into, improve and extend its existing programs that have been, throughout the last decade, helping boost academic entrepreneurship and spin-off creation. Regarding other universities also located in unfriendly environments, we would suggest them to follow the (so far) relatively successful approach developed by UPV in terms of its way of shaping its institutional resources.

Third, as for organizational resources, UPV's TTO, IDEAS Institute and Science Park stand out as assets that have a positive impact on academic entrepreneurship, together with UPV internal regulations that consistently foster academic entrepreneurship. Funding-related initiatives are also worthwhile mentioning, such as the venture capital fund Tech Transfer UPV or the CV-BAN, although their impact has, so far, not been as relevant as expected, in terms of funding support to academic spin offs. Furthermore, other organizational resources have clearly failed to meet expectations, very especially UPV Corporation, a funding initiative aim at making UPV itself participate in spinoff equity, participation of that had to be eventually discontinued. These results are quite similar to previous findings from other studies at entrepreneurial universities, and - as with institutional resources - organizational resources also help UPV counter-balance environmental unfriendliness for academic entrepreneurship. However, in contrast with the excellent strength of institutional resources at UPV, organizational assets show some deficiencies, especially in terms of funding support and opportunities for spin-off creation and development. 
Finally, personal resources also receive a rather positive assessment. Different types of personal (individual and group) characteristics act as triggers for spin-off creation at UPV. Among these characteristics, some personal motivations among UPV academic staff stand out as triggers for spin off creation, insofar they provide additional support to a reflexivity influence that compensates the negative imprinting environmental impact. The highest rated personal motivations among UPV spin-off entrepreneurs refer to applying knowledge to practical ends, increasing personal independence, detecting business opportunities, and achieving new personal challenges. Certainly, in an external environment that is unfriendly for academic entrepreneurship, in the case of UPV these personal motivations seems to act synergistically with favorable institutional and organizational resources, thus explaining the increase in (reflexivity supported) UPV spin-off creation throughout the years of financial and economic crises in Spain. although the (positive) influence of these personal motivations is similar to the results of previous studies, in our investigation their impact as factors that - though reflexivity - help counter-balance (negative) environmental imprinting is particularly relevant.

Conversely, still within the scope of personal characteristics, UPV entrepreneurs' influences in their decision to create spin-offs are less significant compared to prior studies' findings. Hence, influences from the attitude of society towards entrepreneurship (as this is in turn quite conservative in Spain), entrepreneurial relatives, other organizations' or fiends' advice, business creation campaigns, or examples of successful companies, all show low degrees of importance for UPV spin-off founders inn their decision to create their businesses. Although these are results that mostly differ from prior investigations, they make sense in the context of our study, as there influences, although categorized within the umbrella of personal characteristics, are rooted in external triggers, i.e. heavily shaped by the unfriendly environment.

Last, but not least, risk perceptions among UPV spin-off founders are similar to prior studies' results: relatively high but not extreme. The highest of all types of risks among UPV spin-offs is the business-financial risk, consistent with the unfriendly character of the environment. Conversely, the lowest risk is associated to the entrepreneurs' career, result that is possibly explain by the fact that most academic entrepreneurs in Spain - and particularly at UPV - are already tenured.

\section{CONCLUSION}




\subsection{Contribution to theory}

First of all, with our study, by analyzing how different types of external and internal resources jointly affect academic entrepreneurship, we have contributed to addressing a call for studies that approach ASO formation under more integrated considerations of the conditions that support ASO formation, namely a joint analysis of, on the one hand, motivation conditions and, on the other, framework conditions (Kroll 2009). In our framework, motivation conditions are especially related to personal resources, and framework conditions are linked to environmental institutional and organizational resources.

Second, our proposal of an integrated framework for analyzing the different types of factors that help understand and explain academic entrepreneurship, can also be deemed as a contribution to another academic call. We refer here to the need of a better integration of rather fragmented and heterogeneous literature on aspects related to academic entrepreneurship into stronger and more consistent theoretical frameworks (Schmitz et al. 2017).

Third, our investigation illustrates the transformation that universities are undertaking towards fulfilling more entrepreneurial missions in their regional, national, local and cultural social and economic contexts, so they can effectively fulfill their "third mission" (i.e. in addition to teaching and research) of contributing to economic and social development (Yusof and Jain 2010). Our results evidence that this transformation is also visible in entrepreneurshipunfriendly environments experiencing times of austerity. In this respect, the connections and ties across the entrepreneurs' contexts are crucial for innovation and for developing future policies that optimize cross-context synergies (Autio et al. 2014). Accordingly, our study supports the idea that transferring research results through spinoffs is becoming an increasingly relevant practice, fostered by universities through supporting structures and strategies (Wright and Mosey 2012). Indeed, technology transfer through spin-offs allows a bigger and more efficient appropriation of potential surplus value of knowledge produced at universities: inventors of the technology are also the developers into the market.

Fourth, our study has contributed to advance in the understanding of the dynamics of the tension between imprinting and reflexivity (cf., Suddaby et al., 2015) in entrepreneurship-unfriendly environments under a situation of austerity. Specifically, we have observed that the strongest negative imprinting influence is exerted by environmental

factors on personal factors - especially in terms of environmental structural unfriendliness as de-motivating entrepreneurship among the academic community (see figure 3). However, counter-balancing forces have been also observed, especially regarding, on the one hand, the (relatively positive) imprinting influence from (most) institutional 
and (some) organizational factors on personal ones (e.g., UPV history, culture and support mechanisms for ASO creation), and also, on the other hand, the (clearly positive) reflexivity influence from institutional, organizational and personal resources - which jointly act to actively fight environmental unfriendliness (see figure 3 ). In this sense, and consistent with the "Knowledge Spillover Theory of Entrepreneurship", our study also illustrates how academic entrepreneurs' high-quality human capital can effectively seize entrepreneurial opportunities, which are in turn propelled by institutional and organizational-level knowledge spillovers (Acs et al. 2009; Leuden and Lin 2009). Furthermore, and consistent with these reflections, it is worthwhile emphasizing that - at a first impression rather paradoxically - the environmental situation of austerity (which in principle feeds negative imprinting) has eventually fostered ASO creation, so its initial imprinting influence has been outweighed by an inflated reflexivity reaction from institutional, organizational and (especially) personal resources, in fact triggered by austerity itself. A key conclusion here is that, when facing unfriendly environments coupled with austerity situations, universities whose (positive) reflexivity is stronger that (negative) environmental imprinting may effectively boost ASO creation - even more fruitfully than during pre-austerity times. In terms of figure 3, the specific case of UPV is an example of a situation where the joint action of the main positive (imprinting and reflexivity) forces - represented by a (+) symbol in figure 3 - is stronger than the negative influence of the main imprinting force - represented by a (-) symbol in figure 3.

\section{--- Insert Figure 3 here ---}

Fifth, it is important to note that not all universities have the same institutional and organizational conditions to promote spin-off creation. Every university has distinctive resources and capabilities which can crucially determine the amount of spin-off creation and their survival rate. Our study context and setting are characterized by an unfriendly environment for academic entrepreneurship. Besides, this environmental hostility is increased by the current times of austerity wrought by the recent financial and economic crises, particularly deep in Southern Europe (Papaoikonomou et al. 2012), worsening the conditions for academic entrepreneurship. We have focused our study on the Technical University of Valencia (UPV), a young, entrepreneurial and middle-sized Spanish technical university, with a culture, vision and tradition which are heavily focused on applied research, innovation, and knowledge transfer.

Definitely, our investigation shows that, in entrepreneurship-unfriendly environments going through times of austerity, spin-off development seems a good way to obtain additional economic resources for the university and also 
for the researchers. This finding reveals an apparent counter-balancing effect of austerity policies on the negative impact that unfriendly environments have on academic entrepreneurship. That is, the increased hostility for academic entrepreneurship that austerity measures (research budget cuts, salary drops, etc.) add up to structural unfriendliness, have the seemingly paradoxical effect of spurring entrepreneurship among academics, so as to find alternative ways to support financial needs and increase career prospects. After all, this logic makes sense, for an entrepreneurshipunfriendly environment, if coupled with reasonably good working conditions, salary and benefits linked to traditional teaching and research duties of academic staff, does not encourage such staff to engage into alternative, timeconsuming and highly risky entrepreneurial activities. Conversely, substantially worsened working conditions, salary and benefits, may push otherwise conservative academics to take higher risks and become more entrepreneurial. Certainly, although the lesson learnt here cannot be simply that austerity is a key entrepreneurship driver and thus a policy recipe, this thought-provoking outcome should stimulate reflection and trigger the exploration of further research avenues.

\subsection{Managerial and policy implications}

As already mentioned, Spain can be regarded as a structurally unfriendly environment for academic entrepreneurship, coupled with a current condition of austerity in public policies in connection with the recent economic and financial crises. This situation in Spain and its implications, we believe, has a high extrapolation potential to other unfriendly environments under times of austerity, especially in Southern Europe, such as Portugal, Greece or Southern Italy. Having this context in mind, some managerial and policy implications related to the different types of resources (environmental, institutional, organizational and personal) need to be pinpointed - implications applicable to Spanish universities and also to other universities also located un unfriendly, austerity-raven environments. Four implications related to environmental resources open these reflections on managerial and policy implications.

First, Spanish legislation (e.g., LOU 2001; LCTI 2011) regulates knowledge transfer via spin-offs. However, these norms have been hardly successful in promoting spin-off creation. Besides, the specific rules that are aimed at the academic entrepreneur cannot be effective as long as the academic career in Spain is almost exclusively focused on scientific publications and neglects knowledge transfer activities. Hence, further legal changes are necessary if academic entrepreneurship is to be truly encouraged and supported. 
Second, with the recent credit crunch in Spain, and a financial sector highly reluctant to supporting nontraditional business activities (Martínez Carrascal and Mulino Ríos 2014), growth of viable spin-offs becomes very difficult. Self-financing is not enough to exploit temporary opportunities provided by technologies created at university - substantial external investment is essential for spin-off survival and growth. Again, legal changes are necessary in order to provide incentives to investment in knowledge-intensive sectors, along with a culture change in portfolio management by local investors.

Third, our interviewees and survey respondents also noted the apparent paradox that the current situation of crisis could also benefit spin-offs. In this sense, spin-offs' focus on innovation may make them especially attractive to "non-mainstream" entrepreneurs and investors. These agents may consider the disappearance of traditional companies as an opportunity to explore target new market segments eager to welcome future-oriented and changeresponsive businesses.

Fourth, other initiatives could attract foreign, powerful companies to Spanish universities' science parks, so they can set examples for other companies, and exogenously generate local dynamics - as Ford and IBM did in the past in the Region of Valencia.

All in all, transforming environmental resources, so their unfriendliness is decreased, would help build a better business context focused on higher value-added activities, employing more qualified workforce, etc. Such an impact should be fostered by a synergistic action of culture-transforming legal changes, university initiatives, and of course the spin-offs themselves. Given their characteristics, ASOs may be a potentially useful tool - albeit at a small scale - for transforming environmental factors.

Regarding institutional resources (O'Shea et al. 2008), UPV's mission, vision, tradition and history clearly support spin-off creation, and several activities are continuously developed to foster it. On the one hand, UPV can boost many initiatives to support and extend entrepreneurship-friendly culture change. For instance, launching initiatives that bring together projects and investors should be encouraged further and multiplied - as we already find in UPV examples such as CV-BAN and the Tech Transfer UPV venture capital fund. Hence, we would advise UPV to go on with its current institutional strategy of support to academic entrepreneurship. On the other hand, we would recommend other universities also affected by crisis-led austerity and located in unfriendly environments (e.g., throughout Spain, and also in Portugal, Greece or Italy), to follow the example of UPV as a good practice case. 
Concerning organizational resources, our study reinforces the idea that universities can support spin-off creation by establishing specific rules that foster such initiatives, in the broader context of university-business knowledge transfer processes. However, our study has also evidenced some shortcomings in our case university. For instance, the role of UPV's business incubator should be revamped, re-directing its goals and role in promoting spinoffs, becoming more deeply involved throughout the whole process of spin-off creation and development.

Also in the context of organizational resources, problems can arise as well regarding universities' participation in spin-offs' equity. UPV Corporation was established with the aim of supervising and managing companies created in the university context. However, this initiative did not succeed, mainly because of (poor) management and (unfavorable) taxation reasons, so UPV Corporation has been inactive so far. Hence, the spin-off creation process could be better managed through some new mechanisms for supporting spin-offs, supervising them and attracting investors more effectively - thus overcoming the aforementioned problems. In this sense, our case study has evidenced the need of putting spin-offs in contact with funding agents, since most of the capital of these businesses comes from the founders themselves. A possible solution to this problem might start by increasing spin-offs' knowledge of the multiple funding agents that are available in the market and interested in these projects. Some of the agents that are less known to UPV spin-offs are "love money", seed capital, corporate ventures, and privately-owned venture capital. For example, UPV brokered the connection between CV-BAN (an external organization aimed at putting in contact academic entrepreneurs with business angels, so access to potential investors can be facilitated) and academic entrepreneurs. However, CV-BAN has not fulfilled its potential as a funding-facilitating agent. Thus, expanding new ways to collaborate with funding agents such as the Tech Transfer UPV venture capital fund is needed.

All in all, although UPV has supportive and well-designed internal regulations, it also has an important weakness in terms of financial support to spin-offs. Notwithstanding the (local) cultural characteristics that probably underlie this problem, expanding collaboration with other (probably mostly foreign) institutions and participating in benchmarking activities (basically as learner) can be an interesting way for UPV to improve these aspects. Similar advice can be given to other universities also located in unfriendly environments going through times of austerity (e.g., universities located in Portugal, Greece or Italy).

As for personal resources, our study highlights their key role in triggering spin-off creation. In this sense, legislation changes seem necessary so academic entrepreneurs can make their academic and entrepreneurial duties fully compatible, especially having in mind that most academic entrepreneurs wait until the later stages of their careers. 
Therefore, young scholars might become more interested in creating spin-offs, instead of being wholly focused on their publication record in order to achieve tenure. In any case, management problems stand out as the origin of specific obstacles for successfully creating ASOs. Since academics are not necessarily good managers, knowledge transfer via spin-offs is more complex than via licensing or patents, whereby management needs are delegated to the licensee or patent purchaser. Hence, specific training in managerial competences to potential academic entrepreneurs is advised to universities wishing to promote successful knowledge transfer via spin-offs. Once spin-offs successfully overcome the creation stage, team issues seem to be relevant for progressing towards effective survival and growth. Regarding motivations to create spin-offs, in the case of UPV entrepreneurs, the application of knowledge to practical uses and wish of independence must be highlighted. These motivations fit the ones emphasized in the extant literature, although there are other motivations that differ from prior studies. In this sense, regarding the wealth motivation, we found mixed results. All in all, UPV is advised to keep on the good track - and other universities in similar contexts are suggested to follow UPV's path - in reinforcing reflexivity capabilities by academic entrepreneurs, so (negative) environmental imprinting forces can be effectively outweighted and ASO can be properly boosted. 


\subsection{Limitations and further research opportunities}

We are aware of some limitations of this investigation. For instance, the lack of comparison groups or the small sample size, which, although having helped us understand a particular case with substantial depth, is not so useful to identify differences with the situation of the spin-off phenomenon in other similarly sized universities. In any case, we are well aware that further research challenges can be triggered by our investigation. On the one hand, it is necessary to go on inquiring into the evolution of ASOs, not only at their creation and initial development stages, but it is also crucial to deepen into the knowledge of the later stages, the long-term success rates, and the relationships with the changes in the different contextual factors that we have studied. On the other hand, our research method could be applied to study the cases of other universities, from Spain or from other countries (including unfriendly contexts such as Portugal, Greece or Italy, and also friendlier ones such as the UK, Germany or Scandinavia). Crossorganizational comparisons based on the spin-off parent institutions characteristics and (friendly vs. unfriendly) contexts may shed insightful light to the better understanding of the academic entrepreneurship phenomenon.

\section{REFERENCES}

Acs, Z.J., Audretsch, D.B. \& Lehmann, E.E. (2013). The knowledge spillover theory of entrepreneurship. Small Business Economics, 41, 757-774.

Alemany, L. (2011). Libro blanco de la iniciativa emprendedora en España. Resource document. ISEAD. http://idl.isead.edu.es:8080/jspui/bitstream/123456789/859/1/658ALElib.pdf. Accessed 31 October 2015.

Algieri, B., Aquino, A. \& Succurro, M. (2013). Technology transfer offices and academic spin-off creation: the case of Italy. Journal of Technology Transfer, 38(4), 382-400.

ARWU (2017). Academic Ranking of World Universities 2017. Resource document. http://www.shanghairanking.com/ARWU2017.html. Accesed 15 August 2017.

Ashcroft, B., Holden, D. \& Low, K. (2004). Potential entrepreneurs and the self employment choice decision. Strathclyde Discussion papers in Economics, 4-16, University of Strathclyde, Glasglow.

Autio, E. \& Kauranen, I. (1994). Technologist-entrepreneurs versus nonentrepreneurial technologists: Analysis of motivational triggering factors. Entrepreneurship \& Regional Development, 6, 315-328. 
Autio, E., Kenney, M., Mustar, P., Siegel, D. \& Wright, M. (2014). Entrepreneurial innovation: The importance of context. Research Policy, 43, 1097-1108.

Bonnacorsi, A., Colombo, M.G., Guerini, M. \& Rossi-Lamastra, C. (2013). University specialization and new firm creation across industries. Small Business Economics, 41, 837-863.

Bruneel, J., Van de Velde, E. \& Clarysse B. (2013). Impact of the type of corporate spin-off on growth. Entrepreneurship Theory and Practice, 37, 943-959.

CampusHabitat5U (2017). International Campus of Excellence. Resource document. UPV. http://campushabitat5u.es/?lang=en. Accessed 5 October 2017.

Chiesa, V. \& Piccaluga, A. (2000). Exploitation and diffusion of public research: The chase of academic spin-offs companies in Italy. R\&D Management, 30, 329-339.

Clark, B.R. (1998). Creating entrepreneurial universities: Organizational pathways of transformation. IAU Press, New York, NY.

Clarysse, B. \& Moray, N. (2004). A process study of entrepreneurial team formation: The case of research-based spinoff. Journal of Business Venturing, 19, 55-79.

Cohen, M., Nelson, R. \& Walsh, J. (2002). Links and impacts: The influence of public research on industrial R\&D. Management Science, 48, 1-23.

Creswell, J.W. \& Clark, V. (2011). Designing and Conducting Mixed Methods Research. SAGE Publications.

De Cleyn, S. H., Braet, J., \& Klofsten, M. (2015). How human capital interacts with the early development of academic spin-offs. International Entrepreneurship and Management Journal, 11(3), 599-621.

Doutriaux, J., \& Peterman, D. (1982). Technology transfer and academic entrepreneurship. Frontiers of Entrepreneurship Research, Babson College Entrepreneurship Research Conference (BCERC). Babson Park, MA, USA.

Eisenhardt, K.M. (1989). Building Theories from Case Study Research. Academy of Management Review, 14(4), 532550.

European Commission (2017). Erasmus 2013-14. Top 500 higher education institutions receiving Erasmus students. Resource document.

EC.http://ec.europa.eu/dgs/education_culture/repository/education/library/statistics/2014/erasmus-receivinginstitutions_en.pdf Accessed 5 October 2017. 
Eurovoc (2017). Mutilingual Thesaurus of the European Union. Resource document. http://eurovoc.europa.eu Accessed 03 February 2017.

Franzoni, C. \& Lissoni, F. (2006). Academic entrepreneurship, patents and spinoffs: Critical issues and lessons for Europe. CESPRI, Università Commerciale “Luigi Bocconi”. Working Paper No. 80.

Fritsch, M. \& Aamoucke, R. (2013). Regional public research, higher education, and innovative start-ups: An empirical investigation. Small Business Economics, 41, 865-885.

Gartner, W.B. (1985). A conceptual framework for describing the phenomenon of new venture creation. The Academy of Management Review, 10, 696-706.

Gartner, W.B. (1988). Who is an entrepreneur? is the wrong question. American Journal of Small Business, 12, 11-32.

Geuna, A. \& Nesta, L.J.J. (2006). University Patenting and its Effects on Academic Research: The merging European Evidence. Research Policy, 35: 790-807.

Gibbert, M. \& Ruigrok, W. (2010). The "What" and "How" of the case Study Rigor: Three Strategies based on Published Work. Organizational Research Methods, 13(4), 710-737.

Gómez Gras, J.M., Galiana Lapera, D. R., Mira Solves, I., Verdú Jover, A. J., \& Sancho Azuar, J. (2008). An empirical approach to the organisational determinants of spin-off creation in European universities. International Entrepreneurship and Management Journal, 4(2), 187-198.

Grandi, A. \& Grimaldi, R. (2005). Academics' organizational characteristics and the generation of successful business ideas. Journal of Business Venturing, 20(6), 821-845.

Güemes, J.J. (dir.) (2011), “Global Entrepreneurship Monitor. Informe GEM España 2010”. Resource document. GEM España. http://www.gemconsortium.org/docs/download/616. Accessed 15 January 2015.

Guerrero, M. \& Urbano, D. (2012). The development of an entrepreneurial university. Journal of Technology Transfer, $37(1), 43-74$.

Guerrero, M., Urbano, D., Cunningham, J. \& Organ, D. (2014). Entrepreneurial universities in two European regions: a case study comparison. Journal of Technology Transfer, 39(3), 415-434.

Hoang, H., \& Antoncic, B. (2003). Network-based research in entrepreneurship: A critical review. Journal of Business Venturing, 18(2), 165-187.

Hofstede, G. (1980). Culture's Consequences. International differences in work-related values. Sage, Beverly Hills, CA. 
Hofstede, G. (2001). Culture's consequences: Comparing values, behaviours, institutions, and organizations across nations (2nd ed.). Sage, Thousand Oaks, CA.

Hülsbeck, M. \& Pickavé, E.N. (2014). Regional knowledge production as determinant of high-technology entrepreneurship: Empirical evidence for Germany. International Entrepreneurship and Management Journal, 10, 121-138.

INE (2016). INEbase: Operaciones estadísticas. Instituto Nacional de Estadística (National [Spanish] Statistical Institute). Resource document. INE. http://www.ine.es/inebmenu/indice.htm. Accessed 2 July 2016.

Kalar, B., \& Antoncic, B. (2015). The entrepreneurial university, academic activities and technology and knowledge transfer in four European countries. Technovation, 36-37, 1-11.

Kroll, H. (2009). Demonstrating the instrumentality of motivation oriented approaches for the explanation of academic spin-off formation - an application based on the Chinese case. International Entrepreneurship and Management Journal, 5, 97-116.

LAEI (2013). Ley 14/2013, de 27 de septiembre, de Apoyo a Emprendedores y su Internacionalización ('Act of Support to Entrepreneurs and their Internationalization'). Government of Spain, 27 September. Resource document: http://www.boe.es/boe/dias/2013/09/28/pdfs/BOE-A-2013-10074.pdf. Accessed 10 March 2016.

Lam, A., \& De Campos, A. (2015). Content to be sad' or 'runaway apprentice'? The psychological contract and career agency of young scientists in the entrepreneurial university, Human Relations, 68(5), 811-841.

LCTI (2011). Ley 14/2011, de 1 de junio, de la Ciencia, la Tecnología y la Innovación ('Science, Technology and Innovation Act'). Government of Spain, 1 June. Resource document: http://www.boe.es/boe/dias/2011/06/02/pdfs/BOE-A-2011-9617.pdf. Accessed 10 March 2016.

LES (2011). Ley 2/2011, de 4 de marzo, de Economía Sostenible ('Sustainable Economy Act'). Government of Spain, 4 March, Resource document. http://www.boe.es/boe/dias/2011/03/05/pdfs/BOE-A-2011-4117.pdf. Accessed 10 March 2016.

León-Darder, F. (2016). La internacionalització de l'empresa valenciana. In E. Seguí-Mas (Ed.) Una nova via per a l'empresa valenciana (pp. 61-80). Catarroja: Editorial Afers \& Fundació Nexe.

Leyden, D.P. \& Link, A.N. (2013). Knowledge spillovers, collective entrepreneurship, and economic growth: The role of universities. Small Business Economics, 41, 797-817. 
Lindelöf, P. \& Löfsten, H. (2006). Environmental hostility and firm behavior - An empirical examination of new technology-based firms on science parks. Journal of Small Business Management, 44(3), 386-406.

Link, N. \& Scott, T. (2005). Opening the ivory’s tower door: An analysis of the determinants of the formation of US university spin-off companies. Research Policy, 34, 1106-1112.

Lockett, A., \& Wright, M. (2005). Resources, capabilities, risk capital and the creation of university spin-out companies. Research Policy, 34, 1043-1057.

LOU (2001). Ley Orgánica 6/2001, de Universidades ('University Act'). Government of Spain, 21 December. Resource document: https://www.boe.es/boe/dias/2001/12/24/pdfs/A49400-49425.pdf. Accessed 11 March 2016.

LOMLOU (2007). Ley Orgánica 4/2007, de 12 de abril, por la que se modifica la Ley Orgánica 6/2011, de 21 de diciembre, de Universidades ('Act of Modification of the University Act'). Government of Spain, 12 April. Resource document. https://www.boe.es/boe/dias/2007/04/13/pdfs/A16241-16260.pdf (accessed 11 March 2016).

Martinelli, A., Meyer, M., \& Von Tunzelmann, N. (2008). Becoming an entrepreneurial university? A case study of knowledge exchange relationships and faculty attitudes in a medium-sized, research-oriented university. Journal of Technology Transfer, 33, 259-283.

Martínez Carrascal, C. \& Mulino Ríos, M. (2014). La evolución del crédito bancario a las empresas españolas según su tamaño. Un análisis basado en la explotación conjunta de la información de la CIR y de la CBI, Boletín Económico - Banco de España, Enero (January), pp. 117-125.

Mathias, B.D., Williams, D.W., \& Smith, A.R. (2015). Entrepreneurial inception: The role of imprinting in entrepreneurial action. Journal of Business Venturing, 30(1), 11-28.

MIET (Spanish Ministry of Industry, Energy and Tourism) (2012). Estadísticas Pyme. Evolución e indicadores. No. 10”, Resource document. http://www.ipyme.org/Publicaciones/ESTADISTICAS_PYME_N10_2011.pdf. Accessed 2 May 2016.

Miles, M.B. \& Huberman, A.M. (2008). Qualitative Data Analysis: an expanded sourcebook. Sage Publications.

Morales-Gualdrón, S.Y., Gutiérrez-Gracias \& Roig Dobón, S. (2009). The entrepreneurial motivation in academia: A multidimensional construct. International Entrepreneurship and Management Journal, 6, 301-317.

Mosey, S., Lockett, A., \& Westhead, P. (2006). Creating network bridges for university technology transfer: The Medici fellowship programme. Technology Analysis and Strategic Management, 18, 71-91. 
Mosey, S., Noke, H. \& Binks, M. (2012b). The influence of human and social capital upon the entrepreneurial intentions and destinations of academics. Technology Analysis and Strategic Management, 24, 893-910.

Mosey, S., \& Wright, M. (2007). From human capital to social capital: A longitudinal study of technology-based academic entrepreneurs. Entrepreneurship, 31, 909-936.

Mosey, S., Wright, M., \& Clarysse, B. (2012a). Transforming traditional university structures for the knowledge economy through multidisciplinary institutes. Cambridge Journal of Economics, 36, 587-607.

Moutinho, R., Au-Yong-Oliveira, M., Coelho, A., \& Manso, J. P. (2016). Determinants of knowledge-based entrepreneurship: an exploratory approach. International Entrepreneurship and Management Journal, 12(1), 171197.

Mowery, D.C.; Nelson, R.R.; Sampat, B.N. \& Ziedonis, A.A. (2001a) The growth of patenting and licensing by US universities: an assessment of the effects of Bayle-Dole Act of 1980. Research Policy, 30(1): 99-119.

Mowery, D.C.; Sampat, B.N. \& Ziedonis, A.A. (2001b) Learning to patent: institutional experience, learning, and the characyeristics of US university Patents after the Bayle-Dole Act, 1981-1992. Management Science, 48(1): 73-89

Ortín, P.; Salas, V.; Trujillo, M.V. y Vendrell, F. (2007). El spin-off universitario en España como modelo de creación de empresas intensivas en tecnología. Ministerio de Industria, Turismo y Comercio. Secretaría General de Industria. Dirección General de Política de la Pyme. Resource document. http://www.ipyme.org/Publicaciones/Informe spinnoff.pdf. Accessed 2 October 2016.

O’Shea, R., Allen, J., Chevalier, A., \& Roche, F. (2005). Entrepreneurial orientation, technology transfer and spinoff performance of US universities. Research Policy, 34, 994-1009.

O’Shea, R., Allen, T., Morse, K., O’Gorman, C., Roche, F. (2007). Delineating the anatomy of an entrepreneurial university: the Massachusetts Institute of Technology Experience. R\&D Management, 37(1), 1-16.

O’Shea, R., Chugh, H., \& Allen, T. (2008). Determinants and consequences of university spinoff activity: A conceptual framework. Journal of Technology Transfer, 33, 653-666.

Papaoikonomou, E., Segarra, P., \& Li, X. (2012). Entrepreneurship in the context of crisis: Identifying barriers and proposing strategies. International Advances in Economic Research, 18, 111-119.

Piperopoulos, P., \& Piperopoulos, G. (2010). Is Greece finally on the right path toward entrepreneurship, innovation, and business clusters?. International Journal of Public Administration, 33(1), 55-59. 
Powers, B., \& McDougall, P. (2005). University startup formation and technology licensing with firms that go public: A resource-based view of academic entrepreneurship. Journal of Business Venturing, 20, 291-311.

Redero San-Román, M. (2002). Origen y desarrollo de la universidad franquista. Studia Zamorensia, 6, 337-352.

Red OTRI (2016). Informe de la Encuesta de Investigación y Transferencia 2014 de las universidades españolas. Resource document. http://www.redotriuniversidades.net/index.php/informa-encuesta/6-encuestaredotri/informa-encuesta-2014/download. Accessed 22 June 2016.

Rodríguez-Gulías, M.J., Rodeiro-Pazos, D., \& Fernández-López, S. (2017). The effect of university and regional knowledge spillovers on firms' performance: an analysis of the Spanish USOs. International Entrepreneurship and Management Journal, 13(1), 191-209.

Rodríguez-San Pedro, L.E. (2014). Las universidades españolas en su contexto historic. Resource document. Universia. http://universidades.universia.es/universidades-de-pais/historia-de-universidades/historia-universidadespanola/pasado-reciente/pasado-reciente-multiplicidad-regimen-autonomico.html. Accessed 28 July 2015.

Samsom, K., \& Gurdon, M., (1990). Entrepreneurial scientist: Organizational performance in scientist-started high technology firms. Frontiers of Entrepreneurship Research, Babson College Entrepreneurship Research Conference (BCERC). Forest Park, MA, USA.

Schmitz, A., Urbano, D., Dandolini, G.A., de Souza, J.A. \& Guerrero, M. (2017). Innovation and entrepreneurship in the academic setting: A systematic literature review. International Entrepreneurship and Management Journal, 13(2), 369-395.

Shane, S., \& Khurana, R. (2003). Bringing individuals back in: The effects of career experience on new firm founding. Industrial and Corporate Change, 12, 519-543.

Shapero, A., \& Sokol, L. (1982). The social dimensions of entrepreneurship, in Kent, C.A. Sexton, D.L. and Vesper, K.H. (Eds.), Encyclopaedia of entrepreneurship (pp. 72-90). Englewood Cliffs, NJ: Prentice Hall.

Smilor, R.W., Gibson, D.V., \& Dietrich, G.B. (1990). University spin-out companies: technology start-ups from UTAustin. Journal of Business Venturing, 5(1), 63-76.

Soler i Marco, V. (2009). Creixement i canvi estructural. In V. Soler (ed.) Economia espanyola i del País Valencià. Valencia: Publicacions de la Universitat de València.

Suddaby, R., Bruton, G.D., \& Si, S.X., 2015. Entrepreneurship through a qualitative lens: Insights on the construction and/or discovery of entrepreneurial opportunity. Journal of Business Venturing, 30(1), 1-10. 
Tech Transfer UPV FCR (2016). Air Nostrum, Caixa Popular e IVI entran en el fondo de la UPV. Resource document.

TTUPV FCR. http://www.techtransferupv.com/noticias/air-nostrum-caixa-popular-e-ivi-entran-en-el-fondo-dela-upv/ (4 April) Accessed 10 July 2016.

The Times Higher Education (2017). 100 Under 50 Ranking 2017. Resource document. THE. https://www.timeshighereducation.com/world-university-rankings/2017/young-universityrankings\#!/page/0/length/-1/sort_by/rank/sort_order/asc/cols/stats. Accessed 15 august 2017.

UPV (2007). Instituto IDEAS 15 aniversario (1992-2007). Resource document. UPV. http://www.upv.es/entidades/IDEAS/menu_urlv.html?http://www.upv.es/entidades/IDEAS/info/memoria15a\%F1os.pdf. Accessed 10 April 2016.

UPV (2011). Corporación empresarial. Resource document. UPV. http://www.upv.es/noticias-upv/noticia-4904corporacion-emp-es.html. Accessed 10 April 2016.

UPV (2014). Plan de emprendimiento global. Resource document. UPV. https://www.upv.es/noticias-upv/noticia6846-plan-de-emprend-es.html. Accessed 10 April 2016.

UPV (2015). Jornadas de Puertas Abiertas 2015-16. Resource document. UPV. www.upv.es/contenidos/ORIENTA/info/jpa_ciclos_2015-16.ppt. Accessed 10 April 2016.

UPV (2017a). Spin-Off UPV. Resource document. UPV. http://www.upv.es/entidades/I2T/info/891434normalc.html. Accessed 5 October 2017.

UPV (2017b). Ciudad Politécnica de la Innovación. Parque Científico en Red de la Universidad Politécnica de Valencia. Quienes Somos. Presentación. Resource document. UPV. http://cpi.upv.es/quienes-somos/presentacion. Accessed 5 October 2017.

UPV (2017c). Servicio de Promoción y Apoyo a la Investigación, la Innovación y la Transferencia. Presentación. Resource document. UPV. http://i2t.webs.upv.es/i2t/presentacion.php. Accessed 5 October 2017.

UPV (2017d). Tech Transfer UPV. Resource document. UPV. http://www.upv.es/noticias-upv/noticia-8355-tech-transferu-es.html. Accessed 5 October 2017.

UPV (2017e). Mission statement, vision and values. Resource document. UPV. https://www.upv.es/organizacion/lainstitucion/misionvisionvalores-plan-upv-en.html Accessed 17 October 2017.

Vargas Vasserot, C. (2012). Las spin-offs académicas y su posible configuración como empresas de economía social. REVESCO. Revista de Estudios Cooperativos, 107, 186-205. 
VLC/Campus (2017). VLC/Campus. Valencia, International Campus of Excellence. Resource document. UPV. http://www.vlc-campus.com/en. Accessed 5 October 2017.

Walter, A., Auer, M., \& Ritter, T. (2006). The impact of network capabilities and entrepreneurial orientation on university spin-off performance. Journal of Business Venturing, 21(4), 541-567.

Weatherston, J. (1995). Academic Entrepreneurs: Is a spin-off Company too risky. Proceedings of the 40th International Council on Small Business, Sydney, 18-21.

Willoughby, M., Talon, J., Millet, J. \& Ayats, C. (2013). University services for fostering creativity in hi-tech firms. The Service Industries Journal, 33, 1103-1116.

Wright, M., Clarysse, B., Mustar, P. \& Lockett, A. (2007). Academic Entrepreneurship in Europe. Edward Elgar, Cheltenham.

Wright, M., \& Mosey, S. (2012). Strategic entrepreneurship, resource orchestration and growing spin-offs from universities. Technology Analysis and Strategic Management, 24, 911-927.

Yin, R.K. (1994). Case study research: Design and methods (2nd ed.), Sage, Thousand Oaks, CA.

Yusof, M. \& Jain, K.J. (2017). Categories of university-level entrepreneurship: A literature survey. International Entrepreneurship and Management Journal, 6(1), 81-86. 
Figure 1. Evolution of UPV spin-off creation

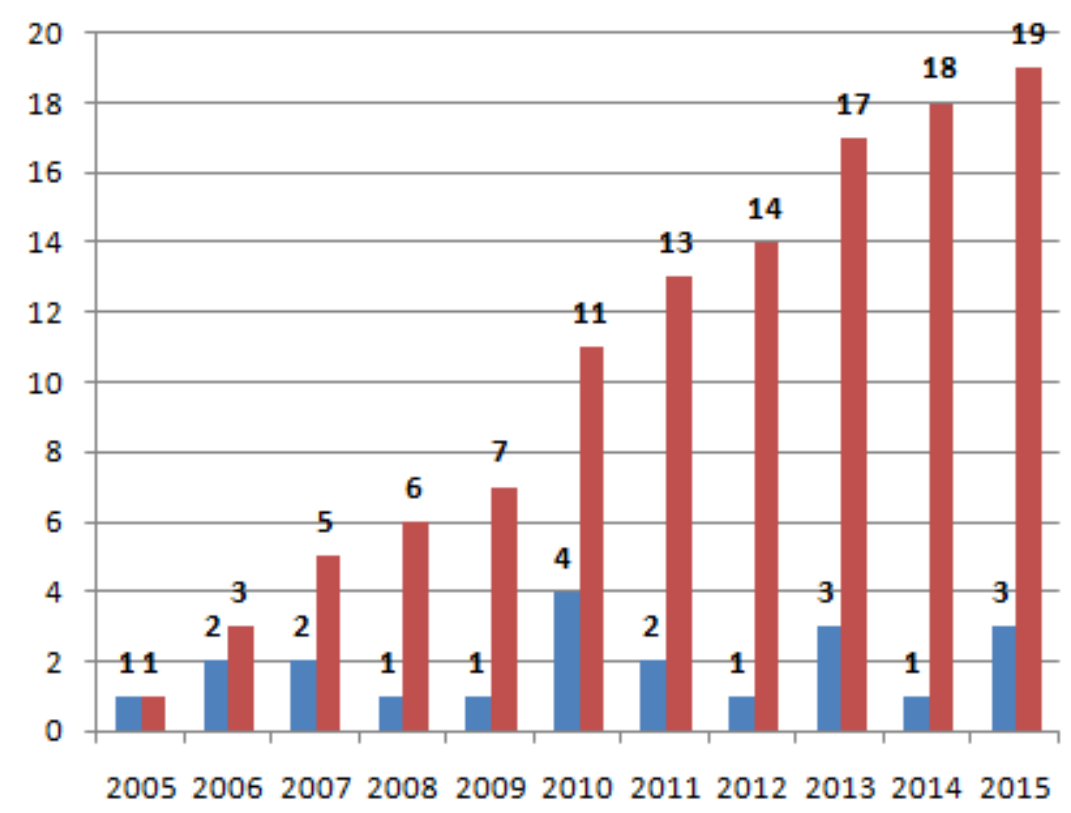

Spin-Off founded at UPV per annum Number of active Spin-Off at UPV 
Figure 2. Funding sources at the time of founding

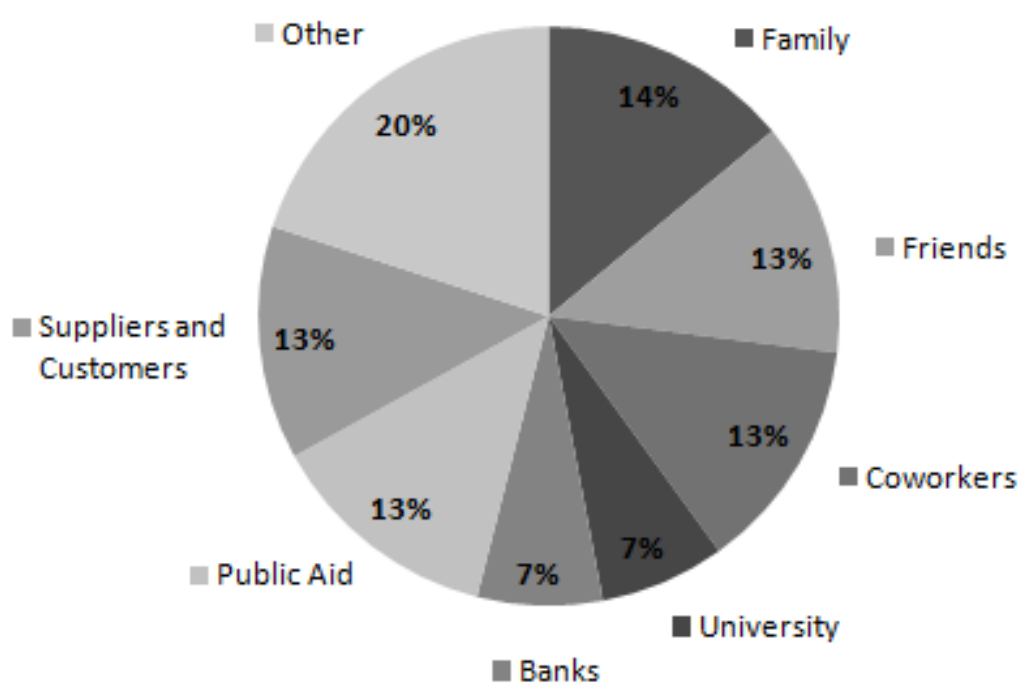


Figure 3. Imprinting vs. reflexivity among the different types of resources for academic spin-off creation. Main influences in unfriendly environments under austerity.

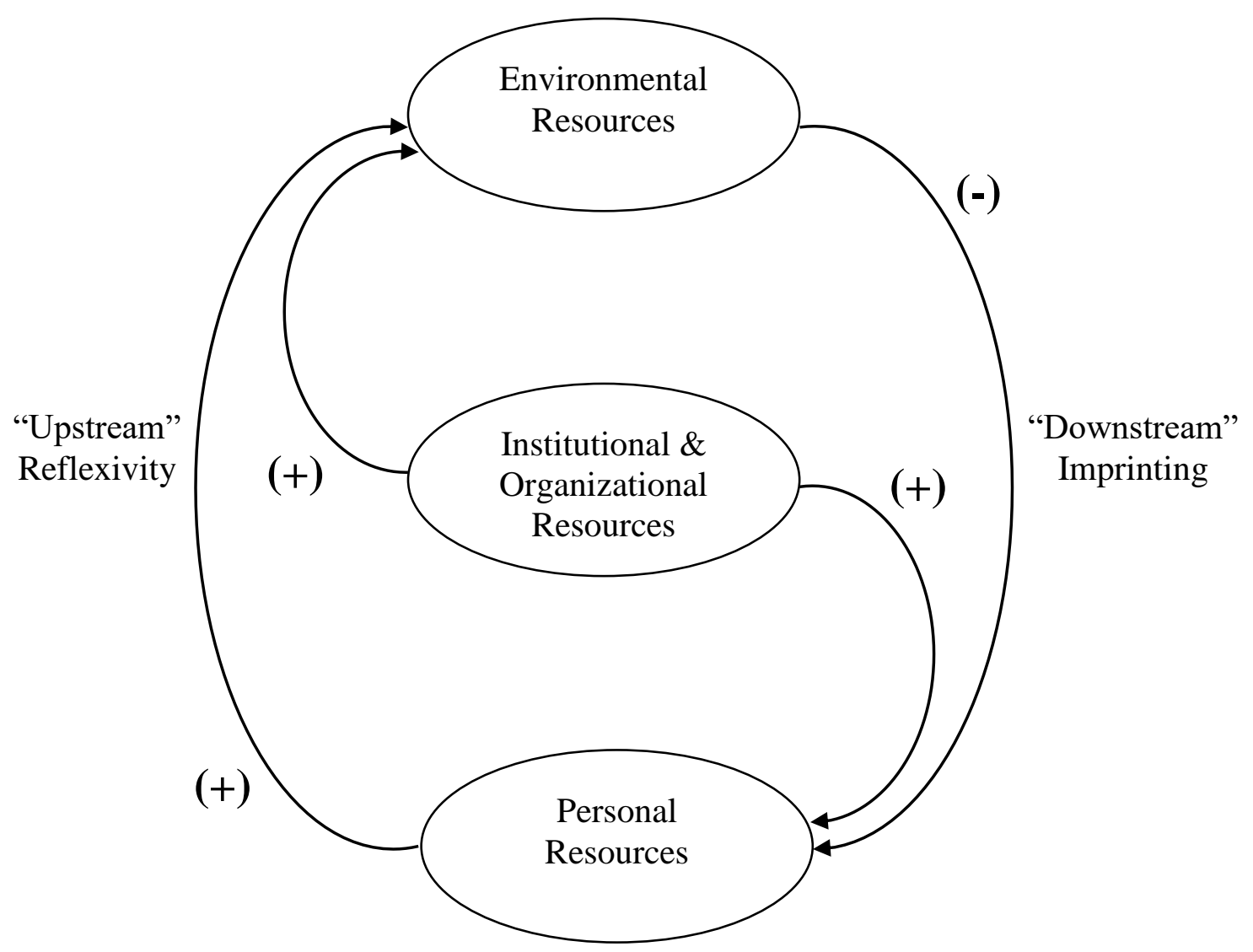


Table 1. Interviews key data.

\begin{tabular}{|c|c|c|}
\hline Interviewee & Position & Time \\
\hline PBL & Professor of Business Law at UPV & $29: 51$ \\
\hline SP & Head of the UPV Science Park & $58: 50$ \\
\hline TTO-V & Vice-Director UPV TTO & $54: 39$ \\
\hline BA & President of CV-BAN & $25: 52$ \\
\hline TTO-H & Head of UPV TTO & $57: 57$ \\
\hline
\end{tabular}


Table 2 Characteristics of UPV spin-offs (2016)

\begin{tabular}{|c|c|c|c|c|c|}
\hline & Company name & Company activity & Staff & $\begin{array}{l}\text { Founding } \\
\text { year }\end{array}$ & Capital \\
\hline 1 & DAS Photonics, S.L. & $\begin{array}{l}\text { Photonic technologies and systems for defence, } \\
\text { security, aviation and satellite industries. }\end{array}$ & 20 & 2005 & $€ 200,000$ \\
\hline 2 & Aurora Sat, S.L. & $\begin{array}{l}\text { CAD tools for satellite-based passive microwave } \\
\text { components. }\end{array}$ & 6 & 2006 & $€ 85,111$ \\
\hline 3 & $\begin{array}{l}\text { Titania Servicios } \\
\text { Tecnológicos, S.L }\end{array}$ & $\begin{array}{l}\text { Technological solutions for industrial maintenance } \\
\text { operations. }\end{array}$ & 5 & 2007 & $€ 60,000$ \\
\hline 4 & ICA 2, S.L. & $\begin{array}{l}\text { Innovation consultancy and knowledge management } \\
\text { applications. }\end{array}$ & 9 & 2007 & N/A \\
\hline 5 & $\begin{array}{l}\text { Advanced Wave } \\
\text { Sensors, S.L. }\end{array}$ & $\begin{array}{l}\text { Acoustic instrumentation in bio-technological and } \\
\text { electrochemical monitoring applications. }\end{array}$ & 8 & 2009 & $€ 3,100$ \\
\hline 6 & $\begin{array}{l}\text { Apeiron Medical, } \\
\text { S.L. }\end{array}$ & Medical devices for oncology surgery. & 1 & 2010 & $€ 29,130$ \\
\hline 7 & $\begin{array}{l}\text { Innoarea Design } \\
\text { Consulting, S.L. }\end{array}$ & Design consulting & 9 & 2010 & $€ 3,060$ \\
\hline 8 & FentISS, S.L & $\begin{array}{l}\text { Technological solutions for real-time embedded and } \\
\text { critical systems using virtualization technologies. }\end{array}$ & N/A & 2010 & N/A \\
\hline 9 & IPresas, S.L. & $\begin{array}{l}\text { Technology services of engineering and consultancy } \\
\text { for military and civil infrastructures. }\end{array}$ & 4 & 2011 & N/A \\
\hline 10 & VLC Photonics, S.L. & $\begin{array}{l}\text { Design of photonic devices and their integration into } \\
\text { microchips. }\end{array}$ & 6 & 2011 & $€ 18,000$ \\
\hline 11 & $\begin{array}{l}\text { Veratech for Health, } \\
\text { S.L. }\end{array}$ & $\begin{array}{l}\text { Software and services focused to Health and Life } \\
\text { Sciences areas. }\end{array}$ & N/A & 2011 & $€ 45,000$ \\
\hline 12 & EYE2021, S.L. & $\begin{array}{l}\text { Development and integration of applications to help } \\
\text { the blind and visually impaired. }\end{array}$ & 1 & 2012 & $€ 20,000$ \\
\hline 13 & $\begin{array}{l}\text { Diseño de Alimentos, } \\
\text { S.L. }\end{array}$ & $\begin{array}{l}\text { Design of high quality food and value-added } \\
\text { services for food service companies. }\end{array}$ & N/A & 2013 & N/A \\
\hline 14 & $\begin{array}{l}\text { Cálculo y } \\
\text { Estructuras } \\
\text { Sensadas, S.L. }\end{array}$ & $\begin{array}{l}\text { Processes and structures monitoring services. Safety } \\
\text { evaluation and services to guarantee a proper } \\
\text { working. }\end{array}$ & 6 & 2013 & $€ 10,000$ \\
\hline 15 & Exos-Solutions, S.L. & $\begin{array}{l}\text { Consulting to improve management processes and } \\
\text { decision-making in companies and organizations. }\end{array}$ & N/A & 2013 & N/A \\
\hline 16 & $\begin{array}{l}\text { Kumori Systems, } \\
\text { S.L. }\end{array}$ & $\begin{array}{l}\text { Tools and services to develop, deploy, maintain and } \\
\text { operate comprehensive SaaS, and to host } \\
\text { applications directly in the cloud. }\end{array}$ & N/A & 2014 & N/A \\
\hline 17 & $\begin{array}{l}\text { Ikasia } \\
\text { Techonologies, S.L. }\end{array}$ & $\begin{array}{l}\text { Micro and nanostructured hybrid materials that is } \\
\text { made by a process of additive manufacturing by a } \\
\text { cold procedure. }\end{array}$ & N/A & 2015 & N/A \\
\hline 18 & Kerionics, S.L. & $\begin{array}{l}\text { Manufacturing of nonporous ceramic membranes to } \\
\text { produce oxygen. }\end{array}$ & N/A & 2015 & N/A \\
\hline 19 & Microbiotech S.L. & $\begin{array}{l}\text { New synergistic applications to improve the Energy } \\
\text { Efficiency of products and industrial processes } \\
\text { while reducing their } \mathrm{CO} 2 \text { Footprint. }\end{array}$ & N/A & 2015 & N/A \\
\hline
\end{tabular}

Source: (UPV 2016b) 
Table 3. Ten most cited words in the interviews

\begin{tabular}{|c|}
\hline Problems \\
\hline Funding \\
\hline Leader \\
\hline Team \\
\hline Finance \\
\hline Difficulties \\
\hline Motivations \\
\hline Context \\
\hline Support \\
\hline Risk \\
\hline
\end{tabular}

Table 4. Categorization and keywords used.

\begin{tabular}{|c|c|c|c|}
\hline Categories & FUNDING CONTEXT & ORGANIZATION & PEOPLE \\
\hline \multirow{4}{*}{ Keywords } & Problems & Problems & Leader \\
\cline { 2 - 4 } & Funding & Difficulties & Team \\
\cline { 2 - 4 } & Finance & Support & Problems \\
\cline { 2 - 4 } & Difficulties & Resources & Motivations \\
\cline { 2 - 4 } & Aids & & Manager \\
\cline { 2 - 4 } & Capital & & Networking \\
\cline { 2 - 4 } & Risk & & \\
\cline { 2 - 4 } & SME & & \\
\cline { 2 - 4 } & \multicolumn{2}{|c}{} & \\
\hline
\end{tabular}


Table 5. Financial structure of UPV spin-offs at the time of data collection

\begin{tabular}{|l|c|}
\hline & $\%$ of funding/liabilities \\
\hline Founders & $69.3 \%$ \\
\hline Friends and family & $12.7 \%$ \\
\hline Venture Capital & $6.4 \%$ \\
\hline University & $5.8 \%$ \\
\hline Suppliers (debt) & $5.8 \%$ \\
\hline Financial institutions & $0.0 \%$ \\
\hline
\end{tabular}

Table 6. Perception about procedures for public subsidies

\begin{tabular}{|l|c|}
\hline Easy and quick & $0 \%$ \\
\hline Some difficulties (but procedures were quite agile) & $20 \%$ \\
\hline Complicated & $80 \%$ \\
\hline Quite Complicated & $0 \%$ \\
\hline Very Complicated and slow & $0 \%$ \\
\hline
\end{tabular}

Table 7. Perception about evolution of access to funding

\begin{tabular}{|l|c|}
\hline Has improved & $0 \%$ \\
\hline Has not changed & $20 \%$ \\
\hline Has worsened & $80 \%$ \\
\hline Do not know / Not applicable & $0 \%$ \\
\hline
\end{tabular}


Table 8. Impact of problems related to organizational resources that affect UPV spin-offs.

\begin{tabular}{|l|c|c|c|c|c|}
\hline & $\begin{array}{c}\text { No } \\
\text { impact }\end{array}$ & $\begin{array}{c}\text { Some } \\
\text { impact }\end{array}$ & $\begin{array}{c}\text { High } \\
\text { impact }\end{array}$ & $\begin{array}{c}\text { Extreme } \\
\text { impact }\end{array}$ & $\begin{array}{c}\text { Do not know / } \\
\text { Not applicable }\end{array}$ \\
\hline Obtaining institutional support from the university & $14 \%$ & $71 \%$ & $14 \%$ & $0 \%$ & $0 \%$ \\
\hline External promotion of the spin-off & $14 \%$ & $71 \%$ & $14 \%$ & $0 \%$ & $0 \%$ \\
\hline Relationships with the TTO & $29 \%$ & $71 \%$ & $0 \%$ & $0 \%$ & $0 \%$ \\
\hline Relationships with the Science Park & $29 \%$ & $14 \%$ & $0 \%$ & $0 \%$ & $57 \%$ \\
\hline Relationships with spin-off program management & $57 \%$ & $43 \%$ & $0 \%$ & $0 \%$ & $0 \%$ \\
\hline $\begin{array}{l}\text { Relationships with the structures through which UPV } \\
\text { participates in the spin-off capital }\end{array}$ & $29 \%$ & $57 \%$ & $14 \%$ & $0 \%$ & $0 \%$ \\
\hline Relationships with the business incubator & $14 \%$ & $14 \%$ & $0 \%$ & $14 \%$ & $57 \%$ \\
\hline Management of resources in the start-up process & $14 \%$ & $43 \%$ & $0 \%$ & $14 \%$ & $29 \%$ \\
\hline Negotiating office space at the university & $29 \%$ & $29 \%$ & $0 \%$ & $0 \%$ & $43 \%$ \\
\hline
\end{tabular}

Note. Each spin-off was asked to rate each potential problem according to a four-point Likert scale, ranging between "no impact" and "very high impact". Rows show the distribution of answers among spin-offs for each of the potential problems.

Table 9. UPV degree of support in UPV spin-off creation.

\begin{tabular}{|c|c|c|c|c|c|}
\hline & None & Some & High & $\begin{array}{l}\text { Very } \\
\text { high }\end{array}$ & $\begin{array}{l}\text { Do not know / } \\
\text { Not applicable }\end{array}$ \\
\hline Advice on business plan development & $0 \%$ & $29 \%$ & $0 \%$ & $71 \%$ & $0 \%$ \\
\hline Legal advice & $29 \%$ & $29 \%$ & $29 \%$ & $14 \%$ & $0 \%$ \\
\hline Bureaucracy advice & $29 \%$ & $43 \%$ & $29 \%$ & $0 \%$ & $0 \%$ \\
\hline Help with business contacts & $43 \%$ & $43 \%$ & $14 \%$ & $0 \%$ & $0 \%$ \\
\hline Financial sources information & $0 \%$ & $29 \%$ & $71 \%$ & $0 \%$ & $0 \%$ \\
\hline Institutional support for business creation & $14 \%$ & $0 \%$ & $29 \%$ & $57 \%$ & $0 \%$ \\
\hline Payment of patent-related costs & $43 \%$ & $0 \%$ & $29 \%$ & $0 \%$ & $29 \%$ \\
\hline Transfer of patent exploitation rights & $29 \%$ & $14 \%$ & $29 \%$ & $29 \%$ & $0 \%$ \\
\hline Transfer or rental of facilities & $14 \%$ & $14 \%$ & $0 \%$ & $43 \%$ & $29 \%$ \\
\hline Reduction of academic duties of the researcher/entrepreneur & $43 \%$ & $43 \%$ & $0 \%$ & $14 \%$ & $0 \%$ \\
\hline Training in business management & $14 \%$ & $43 \%$ & $43 \%$ & $0 \%$ & $0 \%$ \\
\hline Contribution to seed/venture capital & $57 \%$ & $14 \%$ & $14 \%$ & $0 \%$ & $14 \%$ \\
\hline
\end{tabular}


Table 10. Importance of personal motivations for UPV spin-off creation

\begin{tabular}{|l|cccc|c|}
\hline & Unimportant & $\begin{array}{c}\text { Somewhat } \\
\text { important }\end{array}$ & $\begin{array}{c}\text { Quite } \\
\text { important }\end{array}$ & $\begin{array}{c}\text { Very } \\
\text { important }\end{array}$ & Mean \\
\hline Applying knowledge to practical ends. & $0 \%$ & $0 \%$ & $29 \%$ & $71 \%$ & $\mathbf{3 . 7 1 4}$ \\
\hline Increasing personal independence. & $0 \%$ & $14 \%$ & $28 \%$ & $57 \%$ & $\mathbf{3 . 4 2 9}$ \\
\hline Identifying a business opportunity (an unfulfilled need). & $0 \%$ & $0 \%$ & $71 \%$ & $29 \%$ & $\mathbf{3 . 2 8 6}$ \\
\hline Achieving new personal challenges. & $0 \%$ & $14 \%$ & $43 \%$ & $43 \%$ & $\mathbf{3 . 2 8 6}$ \\
\hline Developing own ideas. & $0 \%$ & $14 \%$ & $57 \%$ & $29 \%$ & $\mathbf{3 . 1 4 3}$ \\
\hline Improving personal work environment. & $0 \%$ & $29 \%$ & $43 \%$ & $29 \%$ & $\mathbf{3 . 0 0 0}$ \\
\hline Advancing technological knowledge. & $14 \%$ & $14 \%$ & $43 \%$ & $29 \%$ & $\mathbf{2 . 8 5 7}$ \\
\hline Increasing personal wealth. & $14 \%$ & $29 \%$ & $29 \%$ & $29 \%$ & $\mathbf{2 . 7 1 4}$ \\
\hline Putting into practice own ability in business creation & $0 \%$ & $43 \%$ & $43 \%$ & $14 \%$ & $\mathbf{2 . 7 1 4}$ \\
\hline Compensating for poor perspectives in current job. & $14 \%$ & $57 \%$ & $29 \%$ & $0 \%$ & $\mathbf{2 . 1 4 3}$ \\
\hline
\end{tabular}

Table 11. Entrepreneurs' influences on the decision of launching a UPV spin-off

\begin{tabular}{|l|cccc|c|}
\hline & Unimportant & $\begin{array}{c}\text { Somewhat } \\
\text { important }\end{array}$ & $\begin{array}{c}\text { Quite } \\
\text { important }\end{array}$ & $\begin{array}{c}\text { Very } \\
\text { important }\end{array}$ & Mean \\
\hline Examples from successful companies. & $29 \%$ & $29 \%$ & $43 \%$ & $0 \%$ & $\mathbf{2 . 1 4 3}$ \\
\hline Campaigns for fostering business creation. & $43 \%$ & $29 \%$ & $29 \%$ & $0 \%$ & $\mathbf{1 . 8 5 7}$ \\
\hline A friend's advice. & $57 \%$ & $0 \%$ & $43 \%$ & $0 \%$ & $\mathbf{1 . 8 5 7}$ \\
\hline Advice from another organization. & $57 \%$ & $14 \%$ & $29 \%$ & $0 \%$ & $\mathbf{1 . 7 1 4}$ \\
\hline Influence from entrepreneurial relatives. & $71 \%$ & $0 \%$ & $29 \%$ & $0 \%$ & $\mathbf{1 . 5 7 1}$ \\
\hline Attitude in society towards entrepreneurship. & $71 \%$ & $29 \%$ & $0 \%$ & $0 \%$ & $\mathbf{1 . 2 8 6}$ \\
\hline
\end{tabular}

Table 12. Perception of risk associated to UPV spin-off creation.

\begin{tabular}{|l|cccc|c|}
\hline & None & Low & Quite & High & Mean \\
\hline Business financial risk. & $0 \%$ & $14 \%$ & $71 \%$ & $14 \%$ & $\mathbf{3 . 0 0 0}$ \\
\hline Personal financial risk. & $0 \%$ & $14 \%$ & $86 \%$ & $0 \%$ & $\mathbf{2 . 8 5 7}$ \\
\hline Professional career risk. & $29 \%$ & $57 \%$ & $14 \%$ & $0 \%$ & $\mathbf{1 . 8 5 7}$ \\
\hline
\end{tabular}


Table 13. Influence of the different types of resources on UPV spin-off creation

\begin{tabular}{|c|c|c|c|c|}
\hline $\begin{array}{l}\text { Resource } \\
\text { categories }\end{array}$ & Resource types & Selected prior studies & $\begin{array}{l}\text { Influence on } \\
\text { UPV spin-off } \\
\text { creation } \\
\end{array}$ & $\begin{array}{c}\text { Comparison } \\
\text { (UPV vs. prior studies) } \& \\
\text { recommendations }\end{array}$ \\
\hline $\begin{array}{l}\text { Environmental } \\
\text { (E) }\end{array}$ & 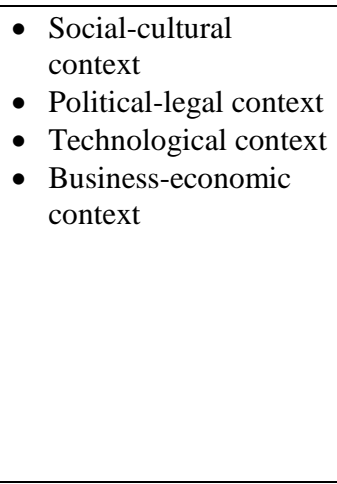 & $\begin{array}{l}\text { - Autio et al. (2014) } \\
\text { - Bruneel et al. (2013) } \\
\text { - Guerrero \& Urbano (2012) } \\
\text { - Hoang \& Antoncic (2003) } \\
\text { - Martinelli et al. (2008) } \\
\text { - Mathias et al. (2015) } \\
\text { - Moutinho et al. (2016) } \\
\text { - O’Shea et al. (2008) } \\
\text { - Pieropoulos \& Pieropoulos (2010) } \\
\text { - Vasgas Vasserot (2012) } \\
\text { - Walter et al. (2006) }\end{array}$ & $\begin{array}{l}\text { Negative } \\
\text { (external } \\
\text { imprinting on I, } \\
\mathrm{O} \text { and } \\
\text { especially } \mathrm{P} \\
\text { resources) }\end{array}$ & $\begin{array}{l}\text { Rather different from } \\
\text { prior research, mainly due } \\
\text { to the specific research } \\
\text { context at UPV (structural } \\
\text { environmental } \\
\text { unfriendliness and } \\
\text { situation of austerity) } \\
\text { - UPV: foster other types of } \\
\text { resources to counter- } \\
\text { balance environmental } \\
\text { unfriendliness. } \\
\text { Other univ. in UE:* } \\
\text { follow UPV example. }\end{array}$ \\
\hline $\begin{array}{l}\text { Institutional } \\
\text { (I) }\end{array}$ & $\begin{array}{ll}\text { - } & \text { Regulations and } \\
\text { programs } \\
\text { - } \\
\text { Positioning in } \\
\text { international rankings } \\
\text { - } \text { Mission, vision, } \\
\text { history, culture and } \\
\text { tradition. }\end{array}$ & $\begin{array}{l}\text { - } \text { Guerrero et al. (2014) } \\
\text { - Kalar \& Antonic (2015) } \\
\text { - Lockett \& Wright (2005) } \\
\text { - Martinelli et al. (2008) } \\
\text { - Moutinho et al. (2016) } \\
\text { - O'Shea et al. (2008) } \\
\text { - Powers \& McDougall (2005) }\end{array}$ & $\begin{array}{l}\text { Positive } \\
\text { (institutional } \\
\text { level } \\
\text { reflexivity on E } \\
\text { resources, and } \\
\text { imprinting on } \\
\text { O and P } \\
\text { resources) }\end{array}$ & $\begin{array}{l}\text { Similar to prior research, } \\
\text { when considering } \\
\text { entrepreneurial } \\
\text { universities. } \\
\text { - UPV: Deepen into, } \\
\text { improve and extend } \\
\text { existing programs. } \\
\text { Other univ. in UE:* } \\
\text { follow UPV example. }\end{array}$ \\
\hline $\begin{array}{c}\text { Organizational } \\
\text { (O) }\end{array}$ & $\begin{array}{ll}\text { - } & \text { TTO } \\
\text { - } & \text { IDEAS Institute } \\
\text { - } & \text { Science Park (incl. } \\
& \text { venture capital / } \\
& \text { business angels) } \\
\text { - } & \text { UPV Corporation } \\
\text { - } & \text { Other (business plan, } \\
& \text { financial, etc.) support }\end{array}$ & $\begin{array}{l}\text { - Link \& Scott (2005) } \\
\text { - O’Shea et al. (2008) } \\
\text { - Wright et al. (2007) } \\
\text { - Powers \& McDougall (2005) } \\
\text { - Rodríguez-Gulías et al. (2017) } \\
\text { - Clarysse \& Moray (2004) } \\
\text { - Lockett \& Wright (2005) } \\
\text { - Martinelli et al. (2008) }\end{array}$ & $\begin{array}{l}\text { Mixed, but } \\
\text { mainly positive } \\
\text { (organizational } \\
\text { level } \\
\text { reflexivity on E } \\
\text { resources, and } \\
\text { imprinting on P } \\
\text { resources) }\end{array}$ & $\begin{array}{l}\text { - Rather similar to prior } \\
\text { research, when } \\
\text { considering } \\
\text { entrepreneurial } \\
\text { universities. } \\
\text { - Worse situation at UPV in } \\
\text { terms of funding support } \\
\text { and opportunities). } \\
\text { - UPV: Deepen into, } \\
\text { improve and extend } \\
\text { existing programs; } \\
\text { susbtantially improve } \\
\text { funding-related issues. } \\
\text { Other univ. in UE:* } \\
\text { follow UPV example. } \\
\end{array}$ \\
\hline $\begin{array}{l}\text { Personal } \\
\text { (P) }\end{array}$ & $\begin{array}{l}\text { - Personal motivations } \\
\text { - Academic career } \\
\text { expectations } \\
\text { - Entrepreneurs' } \\
\text { influences } \\
\text { - Risk perceptions }\end{array}$ & $\begin{array}{l}\text { - Ashcroft et al. (2004) } \\
\text { - Autio \& Kauranen (1994) } \\
\text { - Chiesa \& Piccaluga (2000) } \\
\text { - De Cleyn et al. (2015) } \\
\text { - Douttriaux \& Peterman (1982) } \\
\text { - Gartner (1985) } \\
\text { - Gónez Gras et al. (2008) } \\
\text { - Grandi \& Grimaldi (2005) } \\
\text { - Guerrero \& Urbano (2012) } \\
\text { - Kroll (2009) } \\
\text { - Morales-Gualdrón et al. (2009) } \\
\text { - Mosey \& Wright (2007) } \\
\text { - Mosey et al. (2012b) } \\
\text { - Shapero \& Sokol (1982) } \\
\text { - Similor et al. (1990) }\end{array}$ & $\begin{array}{l}\text { Mixed, but } \\
\text { mainly positive } \\
\text { (personal level } \\
\text { reflexivity on } \\
\mathrm{O}, \mathrm{I} \text { and } \\
\text { especially E } \\
\text { resources) }\end{array}$ & $\begin{array}{l}\text { - Rather similar to prior } \\
\text { research, when } \\
\text { considering } \\
\text { entrepreneurial } \\
\text { universities. } \\
\text { - Higher importance of } \\
\text { personal motivations at } \\
\text { UPV, compared to (lower } \\
\text { importance of) } \\
\text { entrepreneurs' influences. } \\
\text { Higher perception of } \\
\text { business-financial risk at } \\
\text { UPV, vs. to (relatively } \\
\text { low) career risk. } \\
\text { - UPV: Deepen into, } \\
\text { improve and extend } \\
\text { existing programs. } \\
\text { Other univ. in UE:* } \\
\text { follow UPV example. }\end{array}$ \\
\hline
\end{tabular}

* UE: unfriendly environments 


\section{APPENDIX}

\section{QUESTIONNAIRE}

\section{FIRM'S CHARACTERISTICS (FC)}

1) Company name

2) Number of employees

3) Revenue

4) Capital

5) What industry does the company belong to?

$\square \mathrm{R}+\mathrm{D} \square$ Software $\square$ Chemistry $\square$ Pharmaceutical $\square$ Biotechnology $\square$ Other (specify):

\section{FUNDING (F)}

6) Which were the funding sources at the time of founding?

$\square$ Family $\square$ Friends $\square$ Coworkers $\square$ University $\square$ Banks $\square$ Public Aids $\square$ Suppliers and Customers $\square$ Other:

7) How do you consider the public subsidies process?

$\square$ Easy and quick $\square$ Some difficulties (but procedures were quite agile) $\square$ Complicated $\square$ Quite Complicated $\square$ Very Complicated and slow

8) Compared to previous years, do you think that access to funding...

$\square$ Has worsened $\square$ Remains the same $\square$ Has improved $\square$ Do not know / Not applicable

\section{III.INSTITUTION/ORGANIZATION RESOURCES (I\&OR).}

9) To what extent did you have problems in each of the following aspects?:

$\square$ No impact $\square$ Some impact $\square$ High impact $\square$ Extreme impact $\square$ Do not know / Not applicable

- Problems with obtaining UPV institutional support

- Problems with UPV external promotion of the spin-off

- Problems with relations with UPV TTO

- Problems with relations with UPV Science Park

- Problems with relations with UPV spin-off program management

- Problems with relations with the structures through which UPV participates in spin-off capital

- Problems with relations with UPV incubator

- Problems with management of resources contributed by UPV

- Problems with negotiating office space at UPV

10) Assess the degree of UPV support in your start-up by contributing the following resources:

None $\square$ Some $\square$ High $\square$ Very high $\square$ Do not know / Not applicable

- Advice on business plan development

- Legal advice

- Bureaucracy advice

- Help with business contacts 
- Financial sources information

- Institutional support for business creation

- Payment of patent-related costs

- Transfer of patent exploitation rights

- Assignment or rental of facilities

- Reduction of academic duties of the researcher/entrepreneur

- Training in business management

- Contribution to seed/venture capital

\section{IV.PEOPLE: PERSONAL RESOURCES (PR)}

11) Below there are some issues related to your personal motivations to launch your own company. What importance do you give to each of them?

$\square$ Unimportant $\square$ Somewhat important $\square$ Quite important $\square$ Very important

- Identifying a business opportunity (an unfulfilled need)

- Putting into practice own ability in business creation

- Developing own ideas

- Increasing personal independence

- Increasing personal wealth

- Improving personal work environment

- Compensating for poor perspectives in current job

- Achieving new personal challenges

- Advancing technological knowledge

- Applying knowledge to practical uses

12) There are some external factors to the organization and the individual that can affect the decision for starting a business. What importance do you give to each of them in your decision to become an entrepreneur?

$\square$ Unimportant $\square$ Somewhat important $\square$ Quite important $\square$ Very important

- Influence from entrepreneurial relatives

- A friend's advice

- Examples from successful companies

- Advice from another organization

- Campaigns for fostering business creation

- Attitude in society towards entrepreneurship

13) What level of risk do you perceive for starting a business in each of the following aspects?

$\square$ None $\square$ Low $\square$ Quite $\square$ High

- Business financial risk

- Personal financial risk

- Professional career risk 